FIU Law Review

Spring 2014

\title{
Copyrights, Trademarks, and Terminations: How Limiting Comic Book Characters in the Film Industry Reflects on Future Intellectual Property Issues for Character Law
}

Joshua Saval

Follow this and additional works at: https://ecollections.law.fiu.edu/lawreview

Part of the Other Law Commons

Online ISSN: 2643-7759

Recommended Citation

Joshua Saval, Copyrights, Trademarks, and Terminations: How Limiting Comic Book Characters in the Film Industry Reflects on Future Intellectual Property Issues for Character Law, 9 FIU L. Rev. 405 (2014). DOI: https://dx.doi.org/10.25148/lawrev.9.2.15

This Comment is brought to you for free and open access by eCollections. It has been accepted for inclusion in FIU Law Review by an authorized editor of eCollections. For more information, please contact lisdavis@fiu.edu. 


\title{
Copyrights, Trademarks, and Terminations: How Limiting Comic Book Characters in the Film Industry Reflects on Future Intellectual Property Issues for Character Law
}

\author{
Joshua Saval*
}

\section{INTRODUCTION}

On October 9, 2012, Stan Lee Media, Inc. sued Disney for copyright infringement involving various Marvel characters including Spider-Man, Iron Man, Thor, Captain America, Hulk, and the X-Men. ${ }^{1}$ This lawsuit is worth billions of dollars, ${ }^{2}$ and is a good example of why intellectual property rights are important, especially for the adaptation of comic book characters in major film franchises.

This article will examine the market power ${ }^{3}$ for comic book characters in the film industry as an example for how fictional characters can be locked up from future creative expression. It will be shown that Warner Bros. Entertainment, Inc. ("WB") and The Walt Disney Company ("Disney") are blocking the use of major comic book characters in the film industry by having vertical agreements with Detective Comics, Inc. (“DC”)

* This comment was authored by Joshua A. Saval, a third-year law student at the Florida International University College of Law. Special thanks to Professors Hannibal Travis and Stephen Carlisle for providing valuable insights to this paper, as well as Joshua L. Simmons of Kirkland \& Ellis LLP and Charlotte Towne of Charlotte Towne, P.A. I also wish to thank the FIU Law Review Editorial Board for their support and their dedication to furthering the success of FIU Law. I would also like to give a special thanks to Michael Uslan, the man who influenced me to become a lawyer and follow entertainment law. I would lastly like to thank my family and friends for putting up with all my talk of comic book characters.

1 Complaint for Copyright Infringement, Stan Lee Media, Inc. v. The Walt Disney Co., No. 1:12-cv-02663 (D. Colo. Oct. 9, 2012), available at http://www-deadline-com.vimg.net/wpcontent/uploads/2012/10/Disney-Marvel-Stan-Lee-copyright-infringement-suit_121010000839.pdf.

2 Dominic Patten, Stan Lee's Former Company Claims Disney Doesn't Own Marvel Superheroes; Wants Billions in Damages, DEADline HollywOOD DAILY (Oct. 9, 2012, 6:47 PM), http://www.deadline.com/2012/10/stan-lee-media-lawsuit-walt-disney-marvel-superheroes-copyrightinfringement/\#more-350808 (worth $\$ 5.5$ billion).

3 Market power asks if a company has "foreclosed a sufficiently large, or crucial, part of the market to effectively block competitors from entering or expanding to compete for new business." Sterling Merch., Inc. v. Nestle, S.A., 724 F. Supp. 2d 245, 263 (D. P.R. 2010). Market Share figures are used "as initial guides for determining if foreclosure rates are facially dubious or presumably harmless, but a significant share is only a presumptive signal of market power as entry barriers may be low." Id. The inference of market power requires a plaintiff to prove that a company "has a dominant share in a relevant market, and that significant 'entry barriers' protect that market.” Id. (citing Broadcom Corp. v. Qualcomm Inc., 501 F.3d 297, 307 (3d Cir. 2007). 
and Marvel Entertainment, Inc. ("Marvel”). Due to WB owning DC and Disney owning Marvel, each film studio owns the comic book publisher's library of characters and can refuse to license those characters while continuing to exploit those characters in their own films.

Using these market conditions as an example, this article argues that copyright duration should not be extended and termination rights should be easier to implement as these are the only available options to free up these characters from the film industry. Some companies argue for copyright extension because of fear of the public domain, but these arguments fail because characters can still be protected after entering the public domain. Termination rights should be made easier for authors who try to retrieve the rights to the characters that they created, because companies have available exceptions to termination rights that allow them to continue to exploit certain uses of the character. ${ }^{4}$

Part I of this Comment will provide a brief outline of copyright and trademark protection for characters in different media. Part I will also describe changes in copyright law through the Copyright Act of 1976, which added termination rights for authors, and the Supreme Court decision in Eldred v. Ashcroft, ${ }^{5}$ which approved the twenty-year extension in copyright duration.

Part II will analyze the market share for comic book characters in the film industry and reveal how the most popular comic book characters are being blocked from the market for other film studios besides WB and Disney. This will affect the film industry by forcing studios who are not allowed to use the most popular comic book characters to either use independent comic book characters or create new ones, neither of which have the mass appeal and financial potential as the famous characters.

Part III will argue that extending copyright protection is unnecessary, because characters can still be protected after entering the public domain; because an extension will not promote independent creation, public domain works will not be overused or underused, and new uses of a public domain work will not negatively affect the original work's worth. Part III will also argue that the termination right should be made easier to exercise because it provides an incentive to authors to disseminate their work, and companies can continue to exploit certain uses of the character for the full copyright

4 This article does not argue for legislative copyright reform in these areas of the law, but rather argues for authors and companies to engage in more cohesive deal-making as well as more clear judgments by courts on separating trademark and copyright law for characters. For an inclusive analysis of possible copyright reforms, read William PATry, HOW TO FIX COPYRIGHT (2011), and JASON Mazzone, Copyfraud ANd Other Abuses of Intellectual PRoperty LAW (2011). See generally Pamela Samuelson, Book Review: Is Copyright Reform Possible, 126 HARV. L. Rev. 740, 740 (2013).

5537 U.S. 186 (2003). 
period.

Part IV will discuss the future of characters and how they can be protected after they enter the public domain, or are returned to the author after a successful termination. Characters that have additional original expression added in derivative works can still be in the public domain or terminated, but those increments of expression added to the characters cannot be used if still under copyright protection. And when a character is no longer protected by copyright law, the main source of protection for a comic book character is trademark law. Use of trademark law to protect public-domain or terminated characters needs to be limited to commercial uses of the character where a company can show secondary meaning, because using trademark law to prevent expressive uses of a character is like granting a form of unlimited copyright.

\section{PART I: OVERVIEW OF COPYRIGHT AND TRADEMARK PROTECTION FOR COMIC BOOK CHARACTERS}

Comic books are closer to the audiovisual medium than literary works because of their pictorial elements. All a comic book needs to become a film is movement and sound. ${ }^{6}$ Comic book characters have graced the silver screen in serials aired before movies and have also appeared on television in cartoons and television shows. ${ }^{7}$ It was not until 1978 that a feature-length movie based on a comic book character was made. ${ }^{8}$ Comic book films are now one of the most popular genres with more than forty films based on comic book characters made within the last twenty years ${ }^{9}$ and another dozen planned for the next decade. ${ }^{10}$

Marvel and DC are two of the oldest comic book publishers and

6 In fact, there has been a trend in creating motion comics, which combines the element of print comics with animation and sound to create a film using the actual comic book art. See Chris Albrecht, The Rise of Motion Comics Online, GIGAOM (July 30, 2008, 12:56 PM), http://gigaom.com/2008/07/30/the-rise-of-motion-comics-online/.

7 A nonexhaustive list featuring only several serials, shows, and cartoons of comic book characters from before or around 1978: Batman serial from 1943, Batman 1960s TV series, Wonder Woman 1970s TV series, Incredible Hulk 1970s-1980s TV series, Spider-Man 1960s cartoon, Captain America 1940s serial, Captain Marvel 1940s serial. See IHC’s Ultimate Live-Action Comic Book Movie and TV Database, IHEARTCHAOS, http://www.iheartchaos.com/comic-book-movies (last visited May 7, 2014).

8 And with complete success. "Superman" the movie made more than $\$ 300$ million worldwide. See Box OFFICE MoJo, http://www.boxofficemojo.com/movies/?id=superman.htm (last visited March 7, 2014).

9 See Splash Page Team, Marvel vs. DC: Who's Winning At The Box Office, MTV SPLASH PAGE (Oct. 1, 2012, 10:25 AM), http://splashpage.mtv.com/2012/10/01/marvel-dc-box-office/ (list of Marvel and DC films).

10 Disney is planning a slew of Marvel movies over the next several years. See Andrew Dyce, Kevin Feige Talks Thanos and the Buildup to Marvel 'Phase Three', SCREEN RANT (Sept. 21, 2012, 12:28 PM), http://screenrant.com/marvel-movies-thanos-rumors-phase-two-three/. 
represent the majority of published comic books in America. ${ }^{11}$ Marvel was founded in 1933. ${ }^{12}$ Marvel is home to almost 8,000 characters, including the popular Iron Man, Spider-Man, Hulk and X-Men. ${ }^{13}$ Marvel originally licensed ${ }^{14}$ the film rights to many of its characters before forming its own movie studio in 2005. ${ }^{15}$ DC was formed in 1934 as National Periodical Publications, but later officially changed its name to DC in $1977 .{ }^{16}$ DC houses thousands of popular characters, including Batman, Superman, Wonder Woman, and Green Lantern. ${ }^{17}$

Disney was formed in the 1920s and has grown to a very significant size by now, owning a motion picture company, a publishing company, amusement parks, and retail stores. ${ }^{18}$ On August 31, 2009, Disney and Marvel entered into a merger agreement, in which Disney would acquire

11 See Publisher Market Shares: 2012, DIAMOND COMIC DISTRIB., http://www.diamondcomics.com/Home/1/1/3/237?articleID=129876 (last visited Mar. 7, 2014) (Marvel and DC represented more than $65 \%$ of comic book retail market share in 2012 and more than $73 \%$ of comic book unit market share in 2012); see also Rich Johnston, Marvel Takes 2013 Comics Marketshare Prize-But Not By Much, BlEEding CoOL (Jan. 8, 2014), http://www.bleedingcool.com/2014/01/08/marvel-takes-2013-comics-marketshare-prize-but-not-bymuch/ (For 2013, the two companies represented more than sixty-three percent of revenue raised and more than seventy percent of comics sold).

12 Frederic Deraiche, Marvel and Disney: A Merger with Character, 2009:1 ILL. Bus. L.J. 15, 15-16, available at http://www.law.illinois.edu/bljournal/post/2009/09/20/Marvel-and-Disney-AMerger-with-Character.aspx.

13 Nicole J. Sudhindra, Marvel's Superhero Licensing, WORLD INTELL. PROP. ORG. MAG., June 2012, at 22, 24, available at http://www.wipo.int/wipo_magazine/en/2012/03/article_0005.html.

14 A license is when a copyright owner allows another to use the property in a way that would violate the owner's right in the property without receiving any interest in the title, usually by paying a contractual fee to the copyright owner. See Christopher M. Newman, A License is Not a "License Not to Sue": Disentangling Property and Contract in the Law of Copyright Licenses, 98 IowA L. REV. 1101, 1114-15 (2013). A big part of a character owner's profits come from licensing agreements where other companies use the character outside the original context, such as including the character in movies or toys. Joshua L. Simmons, Catwoman or the Kingpin: Potential Reasons Comic Book Publishers Do Not Enforce Their Copyrights Against Comic Book Infringers, 33 COLUM. J.L. \& ARTS 267, 288-90 (2010). Comic book publishers are not even in the business of selling comic books, but rather are used as a form of advertising to broaden the appeal of the characters for licensing deals. Id. at 292-93. Films and licensing represented $85.4 \%$ of Marvel's gross profits in 2010. Id. at 303. Licensing of Disney characters alone generates nearly twenty billion dollars per year in retail sales. Andrea K. Walker, The Allure of SpongeBob, BALTIMORE Sun, Jan. 29, 2006, at 1D, available at LEXIS News Library, BALSUN File.

15 Sudhindra, supra note 13, at 25. Marvel originally licensed out many heroes, including Spider-Man, the X-Men, Thor, Iron Man, Hulk, Punisher, Blade, and Ghost Rider. All of these characters have reverted back to Marvel except for Spider-Man (Sony), Fantastic Four (20th Century Fox), and the X-Men (20th Century Fox).

16 Company Overview of DC Comics, Inc., BusinessweEk, http://investing.businessweek.com/research/stocks/private/snapshot.asp?privcapId=7621531 (last visited May 8, 2014).

17 DC Comics, CHACHA, http://www.chacha.com/topic/dc-comics (last visited Mar. 2, 2014).

18 Deraiche, supra note 12, at 15. 
Marvel for $\$ 4.24$ billion. $^{19}$ Disney not only acquired the large cast of Marvel characters, ${ }^{20}$ but also the right to continue making movies based on those characters. ${ }^{21}$

WB is a major movie studio founded in $1923 .^{22}$ It has grown to include an animation studio, a video game studio, and also owns DC as a subsidiary of DC Entertainment. ${ }^{23}$ Both DC and WB are owned by Time Warner. ${ }^{24}$ Nearly every major DC character film has been made by WB. ${ }^{25}$

Copyright and trademark law provide protection for these characters, beginning with print and eventually providing protection for characters in other media, including film.

19 See id.; see also Disney Completes Acquisition of Marvel Entertainment for \$4.24 Billion, DISNEY DREAMING (Dec. 31, 2009), http://www.disneydreaming.com/2009/12/31/disney-completesacquisition-of-marvel-entertainment-for-4-24-billion/.

20 All the ones that are not currently licensed out, which include Spider-Man, X-Men, and the Fantastic Four. See Graeme McMillan, Kevin Feige on Multi-Studio Crossover: 'Never Say Never', THE HOLlYWOOD REPORTER HEAT VISION (Nov. 4, 2013, 2:24 PM), http://www.hollywoodreporter.com/heat-vision/kevin-feige-multi-studio-marvel-653116. Disney also had to make a deal with Paramount because the original deal with Marvel was that Paramount would distribute the company's films. Kim Masters, Disney to Distribute Marvel's 'The Avengers,' 'Iron Man 3', THE HOLlyWOOD REPORTER (Oct. 18, 2010, 12:13 PM), http://www.hollywoodreporter.com/news/disney-distribute-marvels-avengers-iron-31061. Disney dominated the young girls market with its Disney princess line, but now it finally had a chance to enter the young boys demographic with superheroes. See Jim Hill, Looking Back/Looking Ahead at Marvel Entertainment's Merger with The Walt Disney Company, JiM HiLl Media (Apr. 9, 2012, 10:52 PM), http://jimhillmedia.com/editor_in_chief1/b/jim_hill/archive/2012/04/09/looking-back-looking-ahead-atmarvel-entertainment-s-merger-with-the-walt-disney-company.aspx\#.UHjNT1H-iSo ("[Disney] really did lack a property with strong young boy and teenage male affinity. [So by acquiring Marvel Entertainment, Inc.], we’ve now filled that [distribution].”).

21 Disney oversees production, distributing, and marketing for Marvel. See Brent Lang \& Lucas Shaw, Disney Chooses Alan Horn as New Studio Chief, THE Wrap (May 31, 2012, 12:20 PM), http://www.thewrap.com/movies/article/disney-chooses-alan-horn-new-studio-chief-42241. Marvel, like Pixar, is a powerful unit under Disney that runs nearly autonomously. Ronald Grover, Disney Names Hollywood Veteran Horn as Studio Boss, CHI. TRIB. (May 31, 2012), http://articles.chicagotribune.com/2012-05-31/entertainment/sns-rt-us-disney-studioalanhornbre84u17v-20120531_1_dick-cook-rich-ross-pixar-s-john-lasseter.

22 Company History, WARNER BROS, http://www.warnerbros.com/studio/about/companyhistory.html (last visited Mar. 25, 2014).

23 Id.

24 Id.; see Siegel v. Warner Bros. Ent., 542 F. Supp. 2d 1098, 1144 (C.D. Cal. 2008) (“The evidence before the Court reveals that the relevant entities are all closely related entities-parent corporations, wholly and partially-owned subsidiaries, partners, sibling business entities (owned directly or indirectly by the same parent)—although it is not entirely clear to the Court exactly what those relationships have been at all relevant times. This fact alone raises a specter of a 'sweetheart deal' entered into by related entities in order to pay a less than market value fee for licensing valuable copyrights.”).

25 DC films made by WB include Superman, Batman, Green Lantern, and Jonah Hex. See Franchises: DC Comics, Box MoJo, http://boxofficemojo.com/franchises/chart/?id=dccomics.htm (last visited Mar. 25, 2014). 


\section{A. Copyright Law Protects Original and Creative Expression}

Article I Section 8 of the Constitution, known as the Copyright Clause, empowers Congress to "promote the Progress of Science and useful Arts" while limiting the means Congress may adopt in exercising the enumerated power. ${ }^{26}$ Congress is limited to granting rights to authors for "limited Times." ${ }^{27}$ The purpose of the power is the promotion of progress, ${ }^{28}$ and Congress makes use of the power by granting copyright to expressive works. $^{29}$ The rationale for granting an author a copyright in his or her work for a limited time is a trade-off between the costs of limiting access to a work against the benefits of providing incentives to create the work in the first place. $^{30}$

The 1976 Copyright Act provides authors with exclusive rights to reproduce their works, to produce derivative works, ${ }^{31}$ and to publicly perform or display their works. ${ }^{32}$ Works subject to copyright protection are defined by the 1976 Act to include literary works, dramatic works, pictorial and graphic works, motion pictures, and other audiovisual works. ${ }^{33}$ However, copyright protection does not extend to an idea. ${ }^{34}$ Only the expression of an idea will be protected once it has been put into a tangible medium. ${ }^{35}$ This is known as the idea/expression dichotomy. ${ }^{36}$

Congress has always been concerned with an original author's right to

26 U.S. CONST. art. 1 § 8.

27 Id.

28 See Graham v. John Deere Co., 383 U.S. 1, 5 (1966) (holding that the "qualified authority" that the Copyright Clause grants "is limited to the promotion of advances in [science and] the "useful arts'”). Although this case was about patent law, Congress gets both the patent power and the copyright power from the same clause, so both are only meant for "limited times."

29 See Chris Sprigman, The Mouse that Ate the Public Domain: Disney, The Copyright Term Extension Act, and Eldred v. Ashcroft, FindLAW (Mar. 5, 2002), http://writ.news.findlaw.com/commentary/20020305_sprigman.html.

30 Michael Todd Helfand, When Mickey Mouse Is as Strong as Superman: The Convergence of Intellectual Property Law to Protect Literary and Pictorial Characters, 44 STAN. L. Rev. 623, 641 n.101 (1992).

31 A derivative work is a work based upon one or more preexisting works, such as a translation, musical arrangement, dramatization, fictionalization, motion picture version, sound recording, art reproduction, abridgment, condensation, or any other form in which a work may be recast, transformed, or adapted. 17 U.S.C. § 101 (2011).

3217 U.S.C. § $106(2011)$.

3317 U.S.C. § 102(a) (2011).

$34 \quad 17$ U.S.C. § 102(b) (2011).

3517 U.S.C. § 106 (2011).

36 See Sid \& Marty Krofft Television Prods, Inc. v. McDonalds Corp., 562 F.2d 1157, 1170 (9th Cir. 1977) ("[T] copyright and the first amendment. The 'marketplace of ideas' is not limited by copyright because copyright is limited to protection of expression.”). 
use his or her own work, even when granting that right to a third party. ${ }^{37}$ Under the 1909 Copyright Act, if an author granted a third party all of the rights in a work during the first term of copyright protection, the copyright would revert back to the author at the beginning of the renewal term. ${ }^{38}$ But this operation of law quickly faded away because it became standard for authors to assign both the original term and the renewal term in their works after the Supreme Court approved of this practice. ${ }^{39}$

In the 1976 Act, Congress provided authors (or heirs) a means by which they could terminate prior grants of copyrighted works in order to renegotiate agreements that did not provide the author adequate compensation for the value of the work. ${ }^{40}$ The termination right is "intended to relieve authors of the consequences of ill-advised and unremunerative grants that had been made before the author had a fair opportunity to appreciate the true value of his work product." 41 The termination right cannot be transferred to a third party by the author or the author's heirs because the termination right is inalienable. ${ }^{42}$ Thus, even if a contract states an author assigns or waives his right to terminate the grant of copyright, the author may still terminate the grant after the required time has passed. ${ }^{43}$

Congress had two rationales for the termination provisions. ${ }^{44}$ The first was to protect young authors who might assign their copyrights for little compensation. ${ }^{45}$ The second was to allow authors the right to recapture a prior grant so they could exploit their works as if they had entered the

37 Edward E. Weiman et al., Copyright Termination for Noncopyright Majors: An Overview of Termination Rights and Procedures, 24 No. 8 INTELL. PROP. \& TECH. L.J. 3, 4 (2012).

38 See Copyright Act of 1909, ch. 320 § 23, 35 Stat. 1075, 1080 (1909). This reversion of the renewal right would allow authors to renegotiate better deals depending on the new value of the work. Michael J. Bales, The Grapes of Wrathful Heirs: Terminations of Transfers of Copyright and "Agreements to the Contrary", 27 CARDOZO ARTS \& ENT. L.J. 663, 666 (2010); see also Jesse J. Krueger, Copyright and Kryptonite: The Failings of Intellectual Property Law Through the Eyes of Superman, 14 DUQ. BUS. L.J. 229, 233 (2012).

39 See Fred Fisher Music Co. v. M. Witmark \& Sons, 318 U.S. 643, 657-58 (1943).

40 See 17 U.S.C. §§ 203, 304(c) (2011); Bales, supra note 38, at 664.

41 Mills Music, Inc. v. Snyder, 469 U.S. 153, 172-73 (1985); see also Scorpio Music S.A. v. Willis, No. 11cv1557, 2012 U.S. Dist. LEXIS 63858, at*10-11 (S.D. Cal. May 7, 2012) (“The purpose of the Act was to safeguard authors against unremunerative transfers and address the unequal bargaining positions of authors, resulting in part from the impossibility of determining a work's value until it has been exploited.”); Classic Media, Inc. v. Mewborn, 532 F.3d 978, 984 (9th Cir. 2008).

42 See Stewart v. Abend, 495 U.S. 207, 230 (1990).

43 The language in the termination provisions state that termination "may be effected notwithstanding any agreement to the contrary.” 17 U.S.C. §§ 203, 304 (2011); see also Mewborn, 532 F.3d at 985 ("Thus, only once a copyright grant is terminated and the right is reverted to an author or his statutory heirs may the reverted copyright interest be effectively assigned.”).

44 Weiman, supra note 37, at 4.

45 Id. 
public domain. ${ }^{46}$ The author might have intended for the work to fall into the public domain in a set amount of time, but this intent was subverted when Congress extended the time for copyright in the 1976 Act. ${ }^{47}$ The termination provisions therefore allow the author to take the right back. ${ }^{48}$

One exception that prevents an author from asserting termination rights is if the work is made for hire. ${ }^{49}$ The reason is because in a work made for hire, the employer, or person for whom the work was prepared is considered the author, and therefore owns all of the rights afforded by copyright. $^{50}$ Another exception prevents an author from terminating rights to derivative works and other works prepared under the authority of a grant before its termination. ${ }^{51}$ These works may be continued to be exploited after termination of the original grant. ${ }^{52}$

\section{A Visual Depiction of a Character is Unique and Acquires Protection}

Before determining copyright infringement for a character, courts must determine whether the character has copyright protection separate from the work in which it was created. ${ }^{53}$ Two tests have been developed to

$46 \quad I d$.

47 Id.

48 Timing is a critical factor in terminating a grant of copyright, and there are different time periods an author can terminate a grant. See Bales, supra note 38, at 667. Grants executed prior to January 1, 1978, are governed by $\S 304$ of the Copyright Act, which states that an author (or heirs) may terminate the grant during any five-year period commencing on either January 1, 1978, or fifty-six years from the original copyright date, whichever date is later. 17 U.S.C. § 304(c)(3) (2011). The Act also provides a second attempt at termination for a five-year period beginning seventy-five years from the original copyright date. 17 U.S.C. § 304(d)(2) (2011). This provision accompanied the Copyright Term Extension Act and enabled an author to reclaim the rights after the twenty-year extension. See infra, Section 1.C. Grants executed on or after January 1, 1978, are governed by $\S 203$ of the Copyright Act, which states that an author (or heirs) may terminate a grant at any time during the five-year period commencing thirty-five years from the execution of the grant. 17 U.S.C. § 203(a)(3) (2011). However, if the original grant of copyright concerned the right to publish a work, the termination period begins at the end of thirty-five years from the date of publication or at the end of forty years from the date of execution of the grant, whichever term ends earlier. Id. Most of the discussion in this article is limited to works created before 1978 because we have only just reached the thirty-five-year mark from 1978, but the implications of the case law regarding old works terminations will likely affect the new works terminations.

4917 U.S.C. §§ 203(a), 304(c). The Copyright Act defines a work made for hire as "a work prepared by an employee within the scope of his or her employment or as a 'specially ordered or commissioned"' work, if it falls within one of nine specified categories in the statute and there is a signed, written agreement that the work is a work made for hire. Id.; §§ 101(1), 101(2).

5017 U.S.C. $\S 201(b)$ (2011).

5117 U.S.C. §§ 203(b)(1), 304(c)(6)(a) (2011).

52 Id.

53 Jasmina Zecevic, Distinctly Delineated Fictional Characters that Constitute the Story Being Told: Who Are They and Do They Deserve Independent Copyright Protection?, 8 VAND. J. ENT. \& TECH. L. 365, 366 (2006). 
determine whether to extend protection to a character existing outside its original context. ${ }^{54}$ The "sufficiently delineated" test asks whether a character is sufficiently developed to qualify as protectable expression, rather than a mere idea. ${ }^{55}$ The effect of this test is to allow a judge to assess the inherent worth of a character. ${ }^{56}$ The second test for determining character protection is the "story being told" test, which asks whether the character is the story. ${ }^{57}$ This is a very narrow standard because very rarely will a character constitute an entire story rather than a part of the story. ${ }^{58}$

After determining whether a character is copyrightable separate from its story, courts look for copyright infringement by testing the degree of similarity between the allegedly infringing work and the original work. ${ }^{59}$ Analysis of similarity is relatively easy for visually depicted characters because a fact finder can recognize the original character in the infringing work, even if the characters are in different contexts. ${ }^{60}$

$54 \quad I d$.

55 Id. at 369-70. "In other words, the more detail with which a character is described, the greater chance that it will, standing on its own apart from its original context, be afforded copyright protection.” Helfand, supra note 30, at 632 n.44. This test was originally developed in Nichols v. Universal Pictures Corp., 45 F.2d 119, 121 (2d. Cir. 1930). There, Judge Learned Hand held that "the less developed the characters, the less they can be copyrighted; that is the penalty an author must bear for marking them too indistinctly." Id. at 121.

56 Zecevic, supra note 53, at 369-70. Unfortunately, this test diverts attention away from the extent to which the alleged infringing material has copied the character because it turns the focus away from the infringing character toward how much expression the original character has. Id. at 372-76.

57 Id. at 371-72. This test developed from Warner Bros. Pictures, Inc. v. Columbia Broad. Sys., 216 F.2d 945, 950 (9th Cir. 1954). The Court held that "[i]t is conceivable that the character really constitutes the story being told, but if the character is only the chessman in the game of telling the story he is not within the area of the protection afforded by the copyright.” Id. at 950.

58 Zecevic, supra note 53, at 371-72.

$59 I d$. at 386. Under this analysis, a court will "separate the ideas inherent in the character from the expression of those ideas. As applied to characters, this step would involve deciding whether the character is just a general type, i.e. an idea, or whether the character evokes enough expression to be protectable.” Id. at 385. Another analysis under the substantial similarity test is the extrinsic/intrinsic steps. See Sid \& Marty Krofft Television Prods., Inc. v. McDonald’s Corp., 562 F.2d 1157, 1164 (9th Cir. 1977). The extrinsic test compares specific, objective criteria of two works on the basis of an analytic dissection of the following elements of each work-plot, theme, dialogue, mood, setting, pace, characters, and sequence of events. See id. The intrinsic part asks whether the "total concept and feel" of the two works is substantially similar. See id. at 1164, 1167. Thus, a court looks at the similarities and the attributes of the character, which in turn lowers the amount of similarity a plaintiff must show for infringement. See id. at 1166-67. This isolated inquiry that simply asks whether the two characters look and feel alike is similar to trademark's concern of consumer confusion because it looks at the characters from the consumer's perspective. See id. at 1163-65.

60 Zecevic, supra note 53, at 369 (graphically depicted characters do not suffer from the same elusiveness as non-graphically depicted literary characters because it is far simpler to make visual comparisons than to compare abstractions). A graphic character based on a literary character is very likely to receive separate copyright protection as a different character as long as there are distinct differences between the two characters. See Brian Cronin, Comic Book Legends Revealed \#345, CoMIC BOOK RES. (Dec. 16, 2011, 9:25 AM), http://goodcomics.comicbookresources.com/2011/12/16/comicbook-legends-revealed-345/ (Marvel created the character Red Sonja based off the character Red Sonya 
One of the earliest cases dealing with infringement of a comic book character is Detective Comics, Inc. v. Bruns Publications Inc. ${ }^{61}$ DC sued Bruns Publications because of the similarity between DC's Superman and Bruns' Wonderman. ${ }^{62}$ Both characters hid their suit beneath clothing, deflected bullets, leapt great distances, and were champions of justice. ${ }^{63}$ The only difference between the two was Superman's costume was blue and Wonderman's costume was red. ${ }^{64}$ The Court found that the character Wonderman infringed on the character Superman because the infringing character went beyond the general stereotype of a "benevolent Hercules" and "appropriated the pictorial and literary details embodied in the complainant's copyrights." ${ }^{25}$ But the real issue in the case was how not to monopolize the general attributes of a super-powered being to only one company, while precluding copying of creative expression. ${ }^{66}$ The Court noted that "the complainant is not entitled to a monopoly of the mere character of a 'superman' who is a blessing to mankind."67

The "story-being-told" test was limited in Walt Disney Productions $v$. Air Pirates. ${ }^{68}$ Disney sued Air Pirates claiming that its use of Disney characters in an adult-oriented comic constituted copyright infringement. ${ }^{69}$ Air Pirates argued that fictional characters are never copyrightable on their own as a component to a work. ${ }^{70}$ The Court limited the "story-being told" test to literary characters because graphic characters are "more likely to contain some unique elements of expression."71 Where an author adds a visual image of a character, the difficulties associated with delineating the character are reduced. ${ }^{72}$ The court also took notice of the widespread public recognition of the characters involved, including Mickey Mouse. ${ }^{73}$

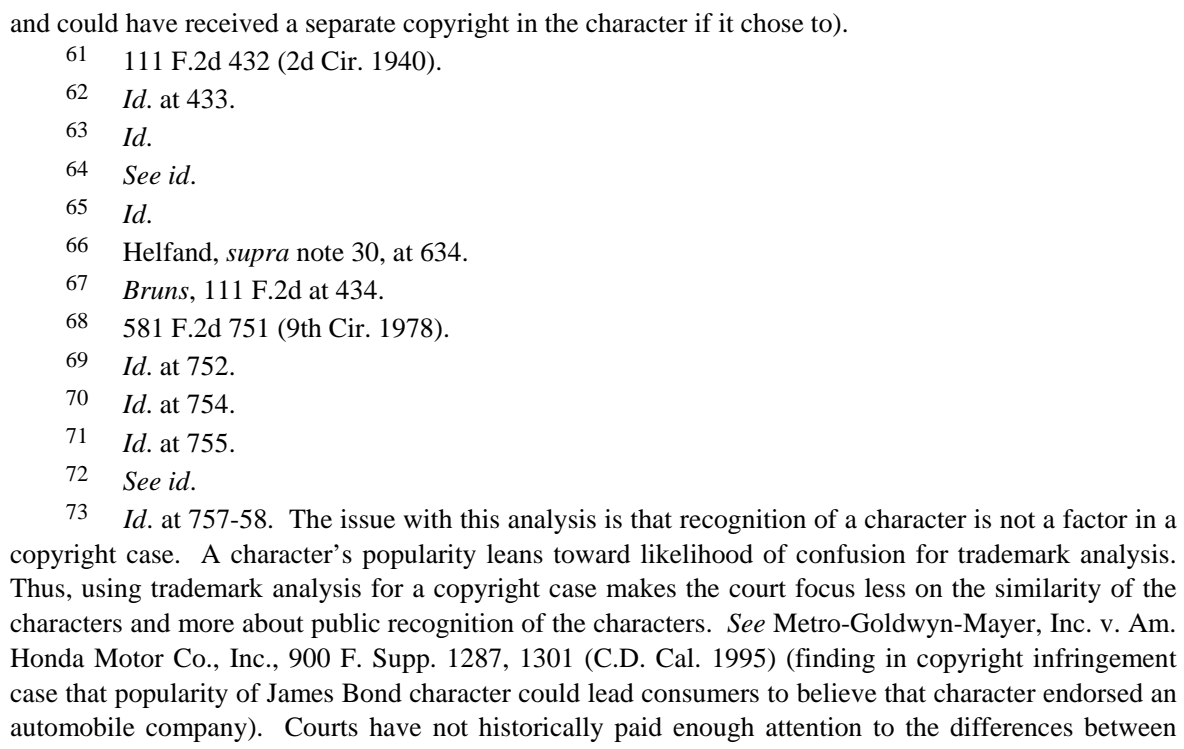

73 Id. at 757-58. The issue with this analysis is that recognition of a character is not a factor in a copyright case. A character's popularity leans toward likelihood of confusion for trademark analysis. Thus, using trademark analysis for a copyright case makes the court focus less on the similarity of the characters and more about public recognition of the characters. See Metro-Goldwyn-Mayer, Inc. v. Am. Honda Motor Co., Inc., 900 F. Supp. 1287, 1301 (C.D. Cal. 1995) (finding in copyright infringement case that popularity of James Bond character could lead consumers to believe that character endorsed an automobile company). Courts have not historically paid enough attention to the differences between 
Copyright infringement for comic book characters in film and television came up in Warner Bros., Inc. v. American Broadcasting Companies, Inc. ${ }^{74}$ The issue for the Court concerned the plaintiff's copyright infringement and unfair competition claims over the defendant's television show "Greatest American Hero" because the show appeared after the success of the recent Superman film. ${ }^{75}$ The Court found no substantial similarity between the two characters under the "look and feel test" because one was heroic and one was a bumbling everyman that was more like a parody of the other hero. ${ }^{76}$ The Court noted that a lack of substantial similarity leaves little basis for asserting a likelihood of confusion under the unfair competition analysis. ${ }^{77}$

Eventually, copyright protection was extended to nearly all visually depicted characters appearing in television or in movies. ${ }^{78}$ The Court in Olson concluded that a visual character is sufficiently expressive to warrant copyright protection. ${ }^{79}$ This idea that a character is copyrightable separate from its original work once it attains a visual image was reaffirmed in Gaiman v. McFarlane, ${ }^{80}$ where the Court held that once the comic book character was drawn into an image, it had developed past the point of an unprotectable idea, and was therefore copyrightable. ${ }^{81}$ Even an inanimate character, such as the Batmobile, can receive copyright protection as a character even though it contains the functional elements of a car, because of the fantastical elements used to create the vehicle. ${ }^{82}$ Thus, visual depictions of characters are protected, and comic book publishers can stop third parties from creating derivative works such as replicas, ${ }^{83}$ fan films, ${ }^{84}$ or costumes based on the characters. ${ }^{85}$

overlapping claims of copyright and trademark made by character owners, which has caused further confusion for the case law. Kathryn M. Foley, Protecting Fictional Characters: Defining the Elusive Trademark-Copyright Divide, 41 CoNN. L. REV. 921, 945-46 (2009).

74720 F.2d 231 (2d Cir. 1983).

75 Id. at 235-38.

76 Id. at 241-43.

77 Id. at 246

78 Olson v. Nat'l Broad. Co., 855 F.2d 1446, 1452 (9th Cir. 1988).

79 Id. at 1451-52 (cases relied upon by the court include Walt Disney Prods. v. Air Pirates, 581 F.2d 751 (9th Cir. 1978) and Warner Bros. v. Am. Broad. Co., 720 F.2d 231 (2d Cir. 1983)).

80360 F.3d 644 (7th Cir. 2004).

81 See id. at 661.

82 Eriq Gardner, Warner Bros. Wins Lawsuit Against Maker of Batmobile (Exclusive), THE HOLLYwOOD REP. ESQUiRE (Feb. 8, 2013, 12:01 PM), http://www.hollywoodreporter.com/thresq/batmobile-lawsuit-warner-bros-wins-419661.

83 See id.

84 See Steve Sunu, Marvel Sends Cease-And-Desist to Anticipated Punisher Fan Film, ComIC BоOK REs. (Oct. 8, 2013, 11:05 AM), http://www.comicbookresources.com/?page=article\&id=48344.

85 See Darryn Bonthuys, Marvel Drops the Lawsuit Hammer on Iron Man Cosplay Factory, LAZY GAMER (Dec. 19, 2013, 5:00 PM), http://www.lazygamer.net/24/marvel-drops-the-lawsuit- 
2. The Termination Right for Characters Revolves Around Renegotiated Agreements After the Right has Vested and Works Made for Hire

One issue that comes with creating a comic book character is determining who owns the copyright in that character. ${ }^{86}$ The owner of a character could either be the author who created it or the company for which the author works, in the case of a work made for hire. ${ }^{87}$ If the work is made-for-hire, then the author cannot terminate a copyright grant because the author never owned the copyright in the first place. ${ }^{88}$ Many comic book authors lament the current condition of having all character work done on a work for hire basis, because then the comic book company can make decisions about the character, without the author's input or having to pay the author a royalty. ${ }^{89}$ Contracts clearly stating who the copyright vested in were not always normal practice, and there have been several fact-intensive cases between comic book authors and the companies they worked for that have tried to determine whether the character was a work for hire. ${ }^{90}$

Joe Simon, co-creator of Captain America, attempted to terminate the copyright grant of the character to Marvel. ${ }^{91}$ As part of a settlement agreement in 1969 regarding prior actions where Simon claimed he was the author of the character, Simon acknowledged that his contribution to the underlying work on the character was done as a work made for hire. ${ }^{92}$ The Second Circuit pointed out, in Marvel Characters, Inc. v. Simon, that the

\footnotetext{
hammer-on-iron-man-cosplay-factory/.

86 John Harleston, Adventures in Copyright: Works Made for Hire and Transfers of Ownership Under the Copyright Act, 22-SEP S.C. LAW. 16, 17 (2010) ("The first essential step in determining ownership of copyright in a work, then, is to determine who the 'author' is.”).

87 See id.

88 See infra Section 1.A.

89 See Todd Allen, Greg Rucka Gets Increasingly Candid About Work For Hire Conditions, Debunks Another Myth, THE BEAT (Sept. 20, 2012), http://comicsbeat.com/greg-rucka-getsincreasingly-candid-about-work-for-hire-conditions-debunks-another-myth/; see also Rob Keyes, Guardians of the Galaxy and Avengers 2 Will Both Feature Thanos, SCREEN RANT (last updated Oct. 30, 2013, 9:21 PM), http://screenrant.com/avengers-2-guardians-galaxy-thanos-villains/2/. This was also one of the issues in Gaiman v. McFarlane, 360 F.3d 644, 648 (7th Cir. 2004). Gaiman was considered to have a copyright interest in the characters he created because he was to be treated better than authors at the other comic book publishers where authors do not receive a copyright interest in characters. Gaiman, 360 F.3d at 649-50.

90 Many of these popular characters were created before the 1976 Act, so the worry behind termination did not exist and contracts were not always specific whether a work was made for hire or whether it was only a grant of rights. Modern contracts take termination rights very seriously and work done for Marvel and DC are considered works-made-for-hire. See Buckler v. Marvel Entm't Group, Inc., No. 91-CV-2167, 1992 WL 210101, *2-3 (S.D.N.Y. Aug. 17, 1992); see also In re Marvel Entm't Group, Inc., 254 B.R. 817, 820 (D. Del. 2000).

91 Marvel Characters, Inc. v. Simon, 310 F.3d 280, 284-85 (2d Cir. 2002).

92 Id. at 283.
} 
Copyright Act allows an author to terminate a prior grant of rights in a work, "notwithstanding any agreement to the contrary."93 Simon presented evidence that he was not an employee for hire when he created Captain America, and the court held Simon was not bound by the statement in the settlement agreement, because it was the type of "agreement to the contrary" that was disavowed under the Copyright Act. ${ }^{94}$ The court found that allowing an agreement made years after the original work was completed to retroactively deem it as a work for hire would frustrate Congress's intent in providing the termination right, and would likely eliminate an author's termination right because publishers could compel authors to agree that work was created for hire. ${ }^{95}$ The parties later settled out-of-court, with the writer granting all rights to the character to Marvel, and Marvel agreeing to return Simon's name as the creator of the famous superhero. ${ }^{96}$ The Simon case has been limited to attempts to reclassify a prior agreement between an author and a grantee. ${ }^{97}$

The heirs of Jack Kirby attempted to terminate the grant of rights in several comic book characters he helped create for Marvel, including the Fantastic Four, the X-Men, and the Incredible Hulk. ${ }^{98}$ The issue for the court was "whether Kirby's work qualifies as work for hire under the Copyright Act of 1909."99 Kirby was a freelance artist at the time, but he did not draw a comic book story until it was approved by the comic writer and he was paid. ${ }^{100}$ The court concluded that Kirby's works were, therefore, works-for-hire because they were created at Marvel's "instance and expense." 101 On appeal, the Second Circuit also held Kirby's work to be works-for-hire because they were made at Marvels "instance and expense" with no agreement to the contrary. ${ }^{102}$

The Superman character has been through several lawsuits determining

93 Id. at 289-92.

94 Id.

95 Id. at 290-91.

96 Ethan Sacks, Joe Simon Dead at 98: Created Captain America with Jack Kirby, DAILY NEWS (Dec. 15, 2011, 2:55 PM), http://articles.nydailynews.com/2011-12-15/news/30522369_1_super-heroboy-commandos-newsboy-legion.

97 Shane Valenzi, It's Only a Day Away: Rethinking Copyright Termination in a New Era, 53 IDEA 225, 239 (2013).

98 Marvel Worldwide, Inc. v. Kirby, 777 F. Supp. 2d 720, 724 (S.D.N.Y. 2011).

99 Id. at 725.

100 Id. at 739 .

101 Id. at 738-43. The "instance and expense test" is used to determine the work made for hire status of an independent contractor for works created under the 1909 Copyright Act. Estate of Hogarth v. Edgar Rice Burroughs, Inc., 342 F.3d 149, 160-62 (2d Cir. 2003). For works created under the 1978 Act, courts will look to the general principles of common law agency. Comm. for Creative NonViolence v. Reid, 490 U.S. 730, 750-51 (1989); Estate of Hogarth, 342 F.3d at 161-62.

102 Marvel Characters, Inc. v. Kirby, 726 F.3d 119, 140-43 (2d. Cir. 2013). 
the outcome of who owns the copyright in the character. ${ }^{103}$ Jerry Siegel and Joe Shuster created Superman in 1938 and sold the rights to the character to National Periodical Publications (now DC) for \$130. ${ }^{104}$ The authors sued DC in 1947, and again in 1969, seeking a determination that they owned the character, but the courts held that DC was the absolute owner of the superhero. ${ }^{105}$ In 1997, the widow and daughter of Siegel served DC with termination notices for Superman in hopes of finally recapturing the rights to the character. ${ }^{106}$ After nearly a decade of litigation, the court held that the Siegel heirs had properly exercised their termination rights in recapturing half of the copyright to Superman. ${ }^{107}$ But on appeal, the Ninth Circuit held the district judge had erred in finding the grant of rights terminated because it did not take into account whether a letter from the heirs's attorney in 2001 "constituted an acceptance of terms negotiated between the parties, and, thus was sufficient to create a contract."108 The court held that the letter did constitute as an acceptance and that the parties had come to an agreement transferring the full rights of Superman to DC. ${ }^{109}$

Following Siegel's initial lawsuit, the heirs of Shuster also filed termination notices with the intent to reclaim the other half of the Superman copyright. ${ }^{110}$ The issue in DC Comics v. Pacific Pictures Corp. was whether an agreement between the heirs and DC in 1992 foreclosed the

103 See Siegel v. Warner Bros. Entm’t Inc., 542 F. Supp. 2d 1098, 1102 (C.D. Cal. 2008); DC Comics v. Pac. Pictures Corp., No. CV 10-3633 ODW (RZx), 2012 WL 4936588, *1 (C.D. Cal. Mar. 26, 2012).

104 Siegel, 542 F. Supp. 2d at 1107.

105 Id. at 1112.

106 Id. at 1114.

107 Id. at 1145 (“After seventy years, Jerome Siegel's heirs regain what he granted so long agothe copyright in the Superman material ....”).

108 Larson v. Warner Bros. Entm’t Inc., 504 Fed. App’x. 586, 587 (9th Cir. 2013).

109 Id. The Siegels then argued that the contract held to be binding is unenforceable because WB never held up its end of the deal. Eriq Gardner, 'Superman' Heirs Still Hope to Grab Rights Back, THE HOLLYWOOD REP. ESQUIRE (Mar. 4, 2013, 5:00 AM), http://www.hollywoodreporter.com/thresq/superman-lawsuit-heirs-still-hope-425728. The latest development in the case is that a federal judge confirmed the enforceability of the 2001 agreement, but the Siegels may have claims against DC for breaching the agreement in a separate breach-of-contract lawsuit. Eriq Gardner, Judge Confirms Warner Bros. Owns Superman, The HOllywood ReP. ESQUiRe (Mar. 21, 2013, 4:17 PM), http://www.hollywoodreporter.com/thr-esq/judge-confirms-warner-bros-owns-430323; see also Kevin Melrose, DC Wins 'Final' Appeal in Long Battle over Superman Rights, CомIC BоOK REs. Rовот 6 (Nov. 22, 2013, 7:00 AM), http://robot6.comicbookresources.com/2013/11/dc-wins-final-appeal-inlong-battle-over-superman-rights/. At the time of this publication, there is still an appeal pending on whether a valid copyright transfer was made. Eriq Gardner, Warner Bros. Gets Another Advantage in Lingering Superman Rights Fight, THE HOLLY WOOD REP. EsQUIRE (Jan. 21, 2014, 2:03 PM), http://www.hollywoodreporter.com/thr-esq/warner-bros-gets-advantage-lingering-672911.

110 DC Comics v. Pac. Pictures Corp., No. CV 10-3633 ODW (RZx), 2012 WL 4936588, at *1 (C.D. Cal. Oct. 17, 2012). 
heirs's rights to terminate the grant of copyright. ${ }^{111}$ The court found that the 1992 agreement settled all prior agreements and released DC from any claims by Shuster's heirs concerning the Superman copyright. ${ }^{112}$

The key issue for a renegotiated agreement is, thus, whether "the author's termination right is vested (the author can terminate at that moment), or remains conditional (the termination right will vest in the future, but the author cannot terminate at the present time)." "113 When an author or the author's heirs re-grant copyrights during a time when they had the opportunity to exercise their termination right, then courts will consider the termination right to be used to renegotiate the terms of the agreement. ${ }^{114}$ The notice of termination period for Superman began in 1984, so the renegotiated agreements in 1992 for Shuster and 2001 for Siegel were executed when the termination right had vested. ${ }^{115}$

\section{B. Trademark Law Protects Marks that Indicate Source and Reputation}

The Lanham Act defines a trademark to include "any word, name,

111 Id. at *2-3. The agreement stated that DC would cover all of Shuster's remaining debts and pay Jean $\$ 25,000$ a year for the rest of her life.

112 Id. at *5. The decision was affirmed later on appeal. See Melrose, supra note 109; see also Jess Goodwin, Warner Bros. Wins Final Piece of 'Superman' Lawsuit, SCREEN RANT, http://screenrant.com/warner-bros-wins-superman-copyright-lawsuit/ (last visited Mar. 8, 2014). This case is considered closed because the Ninth Circuit has denied a petition for rehearing. Kevin Melrose, Appeals Court Denies Shuster Heirs Rehearing in Superman Battle, COMIC BooK RES. RoBOT 6 (Jan. 21, 2014, 2:00 PM), http://robot6.comicbookresources.com/2014/01/appeals-court-denies-shuster-heirsrehearing-in-superman-battle/.

113 Valenzi, supra note 97, at 240. The termination right, therefore, may be considered a contingent right because without the passage of the requisite period of time under the Copyright Act, an author (or heirs) does not have the right to terminate and cannot contract away a right that is not yet owned. Id. at 250.

114 Dallas F. Kratzer III, Up, Up \& Away: How Siegel \& Shuster's Superman Was Contracted Away \& DC Comics Won the Day, 115 W. VA. L. REV. 1143, 1175 (2013). Other cases that have followed this reasoning include termination cases for Winnie the Pooh and the works of John Steinbeck. A.A. Milne's son entered into an agreement in 1983 that specifically revoked prior agreements from 1930 and 1961 concerning the Winnie the Pooh character. Milne v. Stephen Slesinger, Inc., 430 F.3d 1036, 1040 (9th Cir. 2005). The Ninth Circuit concluded that the notice of termination served in 2002 by Milne's granddaughter was ineffective because Milne's son had used the possibility of termination as leverage in forming the new agreement to get a better deal and the termination rights under $\S 304(d)$, which the granddaughter was using, only applies to grants executed before 1978. Id. at 1045. John Steinbeck executed an agreement that established the terms for the publication of some of his most popular novels. Penguin Group (USA) Inc. v. Steinbeck, 537 F.3d 193, 196 (2d Cir. 2008). Steinbeck’s widow entered into a new agreement in 1994 for continued publication of Steinbeck's work, which terminated and superseded any prior grants or rights in the works. Id. at 196-97. Steinbeck's surviving son and grandson served a termination notice in 2004, but the Second Circuit concluded that the 1994 agreement “eliminated the right to terminate the [prior grants] under sections 304(c) and (d).” Id. at 202. For both of these cases, the right to terminate had vested at the time of the renegotiated agreement.

115 Kratzer, supra note 114, at 1181. 
symbol, or device,... [ [used] to identify and distinguish... goods.”116 Trademark law protects against a second comer's use of the same mark, or an imitation of a mark, where it is likely to cause consumer confusion, mistake, or deception. ${ }^{117}$ Trademarks function to identify one seller's goods, to signify that all such goods come from the same source, to signify that all such goods are of an equal level of quality, and to distinguish such goods from those sold by another. ${ }^{118}$ Proof of consumer confusion is the crucial element of a trademark infringement cause of action, and courts employ a likelihood of confusion test that balances a number of factors in order to determine if consumers are or likely will be misled by an allegedly infringing mark. ${ }^{119}$

One important function of a trademark is to reduce search costs for consumers by embodying information such as the reputation of producers or brands of goods. ${ }^{120}$ Trademark law, therefore, balances the cost of granting the exclusive use of a trademark with the benefit of reducing the cost to consumers of searching for a specific product. ${ }^{121}$ The purpose of protecting identifying features in a trademark is not to provide manufacturers with the incentive to develop those features, but to invest in the manufacturer's goodwill. ${ }^{122}$

A significant difference between copyright and trademark protection is that the duration of a trademark is potentially perpetual, provided that the mark is not abandoned or does not lose its indicative qualities. ${ }^{123}$ This potential perpetuity reflects the understanding that trademarks benefit not only the owner of the mark, but consumers who rely on identification of the sponsoring or producing business entity when deciding on a product or service. $^{124}$

116 Lanham Act § 45, 15 U.S.C. § 1127 (2006).

117 Lanham Act § 32, 15 U.S.C. § 1114 (2005).

118 Helfand, supra note 30, at 635-36. A mark's indicative quality is considered secondary meaning. "The prime element of secondary meaning is a mental association in buyers' minds between the alleged mark and a single source of the product.” 2 J. THOMAS MCCARTHY, MCCARTHY ON TRADEMARKS AND UNFAIR COMPETITION § 15:5 (4th ed. 2014); see also Zecevic, supra note 53, at 378 (advantages of trademark and unfair competition laws are protection for the appearance and name of a character and protection of the character even if it is in the public domain).

119 Helfand, supra, note 30, at 636.

120 William M. Landes \& Richard A. Posner, Trademark Law: An Economic Perspective, 30 J.L. \& ECON. 265, 270 (1987).

121 Id. at 269 .

122 Lee B. Burgunder, Trademark and Copyright: How Intimate Should the Close Association Become?, 29 SANTA ClaRA L. REv. 89, 95 (1989).

123 A mark that loses its secondary meaning by becoming a commonly used term will become generic and can be used by anyone. $2 \mathrm{~J}$. THOMAS MCCARTHY, MCCARTHY ON TRADEMARKS AND UNFAIR COMPETITION § 12:1 (4th ed. 2004).

124 Helfand, supra note 30, at 637. 
Another source of protection for trademark holders is an action for dilution, which concerns the weakening of the distinctive quality of a mark or trade name. ${ }^{125}$ Originally a claim under state law, Congress amended the Lanham Act in 1996 by enacting the Federal Trademark Dilution Act (FTDA). ${ }^{126}$ Under the Lanham Act, dilution by tarnishment recognizes an injury when a famous trademark is portrayed in an unwholesome or unsavory context likely to evoke unflattering thoughts about the owner's product. $^{127}$

Dilution is different from trademark infringement in that it does not require a showing of consumer confusion. ${ }^{128}$ Dilution law, thus, protects the distinctiveness of a famous owner's trademark rather than the interest of avoiding consumer confusion. ${ }^{129}$ Fortunately, the FTDA has three statutory exemptions for uses of a trademark that may be dilutive, but are, nevertheless, permitted: comparative advertising, news reporting and commentary, and noncommercial use. ${ }^{130}$ Congress, therefore, did not intend for trademark laws to impinge upon First Amendment rights of critics and commentators because the dilution statute applies only to commercial uses of a mark and explicitly states that the noncommercial use of a mark is not a cause of action for trademark dilution. ${ }^{131}$ These exemptions were added to adequately address legitimate First Amendment concerns by incorporating the concept of commercial speech into trademark dilution analysis. ${ }^{132}$

125 Lanham Act § 43, 15 U.S.C. § 1125(c) (2012).

126 Id

127 Id

128 Lanham Act § 43, 15 U.S.C. § 1125(c)(1) (2012).

1294 J. THOMAS MCCARTHY, MCCARTHY ON TRADEMARKS AND UNFAIR COMPETITION § 24:67 (4th ed. 2014). When dilution was a state law claim, it could be used even where copyright law would allow depiction of a character under fair use and where no trademark violation existed because there was no confusion as to source. Dilution statutes had no First Amendment protections and were extremely powerful for a character mark owner because dilution provided the most expansive protection against the unauthorized use of fictional characters that became indicators of source. Porn parodies utilizing famous characters were therefore considered infringements under dilution. See Pillsbury Co. v. Milky Way Prods., 8 Media L. Rep. (BNA) 1016 (N.D. Ga. 1981) (determining that adult-oriented satire of characters constituted fair use, but nevertheless violate state anti-dilution statute); see Edgar Rice Burroughs, Inc. v. Manns Theatres, 195 U.S.P.Q. (BNA) 159 (C.D. Cal. 1976) (X-rated film entitled “Tarz \& Jane \& Boy \& Cheeta” diluted the value of the registered mark although no proof of confusion had been provided). Under the federal dilution law, porn parodies are allowed using famous character names. In fact, there is an entire porn production company dedicated to superhero porn parodies and the films use the names and likenesses of many famous characters. See Vivid Superhero, WIKIPEDIA, http://en.wikipedia.org/wiki/Vivid_Superhero (last visited Mar. 15, 2013).

130 Lanham Act § 43, 15 U.S.C. 1125(c)(4)(B) (2012); see also Mattel, Inc. v. MCA Records, 296 F.3d 894, 904 (9th Cir. 2002).

131 Lamparello v. Falwell, 420 F.3d 309, 313 (4th Cir. 2005).

132 Id. 
1. Trademark Law Protects Character Marks that Indicate the Source for that Character but Still Allows Expressive, Noncommercial Uses of the Mark

Visual characters have also been affirmed as being able to receive trademark protection. ${ }^{133}$ In a case about whether a publisher could trademark drawings of comic book characters, the court held that a graphic character can function as a protectable mark because of the publisher's efforts to associate each character in the public's awareness with the publisher. ${ }^{134}$ Thus, to establish unfair competition ${ }^{135}$ for a character mark, the mark must emanate from a single source because "lack of a clear source makes it uncertain that the character is truly a mark."136 A trademarked character that loses copyright protection by falling into the public domain can still be protected by trademark law as long as the character mark does not become generic. ${ }^{137}$

The stronger a character mark becomes, "the less interest the owner

1332 J. THOMAS MCCARTHY, MCCARTHY ON TRADEMARKS AND UNFAIR COMPETITION § 10:42 (4th ed. 2014).

134 In re DC Comics, 689 F.2d 1042 (C.C.P.A. 1982). Comic book publishers trademark the images of their characters to protect their stream of commerce and prevent dilution of the image. Krueger, supra note 38, at 235 ("While copyright law protects the graphic representation of the character, trademark law protects the association that the character suggests.”).

135 Unfair competition law is akin to trademark law, but specifically prohibits any false and misleading designations, descriptions, or representations likely to cause confusion or mistake as to source or association, not just the appropriation of distinctive symbols. Lanham Act § 43, 15 U.S.C. § 1125 (2012). Two questions must be answered to determine if infringement under trademark law and unfair competition has taken place. The first is whether the character has achieved "secondary meaning." The second question is whether there is a likelihood of confusion. See Zecevic, supra note 53, at 378. Unfair competition was originally focused against false advertising, but has been read broadly to prohibit any form of "passing off" that might lead to a false and misleading designation of origin. $5 \mathrm{~J}$. THOMAS MCCARTHY, MCCARTHY ON TRADEMARKS AND UNFAIR COMPETITION §§ 27:6-27.8. (4th ed. 2014); see DC Comics, Inc. v. Filmation Assocs., 486 F. Supp. 1273 (S.D.N.Y. 1980) (adopting view that $\S 43(a)$ protects characters, including all their traits and abilities, from copying and imitation by others because an ingredient of the product can symbolize the plaintiff or its product in the public mind). Courts also follow a likelihood of confusion test for unfair competition cases. 5 J. THOMAS MCCARTHY, MCCARTHY ON TRADEMARKS AND UNFAIR COMPETITION § 27:18 (4th ed. 2004).

136 Helfand, supra note 30, at 665; see also Universal City Studios, Inc. v. Nintendo Co., 746 F.2d 112, 116 n.5 (2d Cir. 1984) (noting the lower court's finding "that the King Kong mark lacked distinction and failed to identify the goods it represented as emanating from a particular source" because the rights to the character were divided among a number of companies).

137 See Frederick Warne \& Co. v. Book Sales, Inc., 481 F. Supp. 1191 (S.D.N.Y. 1979). The defendant repackaged several public domain stories about the character Peter Rabbit and used the original cover artwork. Id. at 1194. The court held that a copyrightable character that clearly identifies the source of goods should not be excluded from trademark protection just because it fell into the public domain. Id. at 1197. The court avoided the question of having a perpetual copyright on the characters because the plaintiff sought only to protect the use of specific illustrations of the characters. Id. at 1197 n.3. 
has in tolerating uses that copyright alone otherwise allows.”138 Once a character has become an indicator of source, the owner of the mark will have a great incentive to oversee all character-related uses of the mark because unfavorable uses may damage the goodwill of the owner. ${ }^{139}$ It is in these situations that, more often than not, character mark owners will use trademark law to circumvent what copyright law may allow under fair use. ${ }^{140}$ But trademark law is still subject to exemptions that may allow unflattering uses of a mark. ${ }^{141}$

\section{The Copyright Term Extension Act Shrinks the Public Domain}

The Copyright Term Extension Act (CTEA, also known as the Sonny Bono Act, or the Mickey Mouse Act) was passed in 1998 and extended all copyright protections by twenty years. ${ }^{142}$ The duration of copyright for works created on or after January 1, 1978, was extended to the author's life plus seventy years. ${ }^{143}$ Works made by corporations or works made for hire and works copyrighted after January 1, 1923, but before January 1, 1978, received protection for ninety-five years. ${ }^{144}$ The exclusive rights of the owner are lost once the term of protection ends and the copyrighted work falls into the public domain, making it available for anyone to use. ${ }^{145}$ Tens of thousands of works that were poised to enter the public domain are now maintained by private ownership until at least $2019 .{ }^{146}$ One of these protected works is the most famous rodent in the world, Mickey Mouse. ${ }^{147}$

138 Helfand, supra note 30, at 627.

139 Id

140 See Walt Disney Prods. v. Air Pirates, 581 F.2d 751 (9th Cir. 1978); see also Edgar Rice Burroughs, Inc. v. Metro-Goldwyn-Mayer, Inc., 519 F. Supp. 388 (S.D.N.Y. 1981) (trademark claims against an adult satire of Tarzan).

141 Such as the trademark dilution exemptions. See Section 1.B. infra; see also Smith v. WalMart Stores, Inc., 537 F. Supp. 2d 1302 (N.D. Georgia 2008) (owner of domain names such as WALQUEDA was a successful parody of WAL-MART trademark and not subject to dilution); Mattel, Inc. v. MCA Records, Inc., 296 F.3d 894 (9th Cir. 2002) (Barbie Girl song was a successful parody of the Barbie toy line trademark and not subject to trademark infringement or dilution); Mattel, Inc. v. Walking Mountain Prod., 353 F.3d 792 (9th Cir. 2003) (use of Barbie doll in parodic photographs was fair use and did not infringe or dilute Barbie toy line trademark).

142 Sprigman, supra note 29. It is also known as the Mickey Mouse Act because Disney heavily lobbied for copyright extension since the famous rodent was going to fall into the public domain in 2003. That year, Disney donated more than $\$ 6.3$ million in campaign funds.

143 Eldred v. Ashcroft, 537 U.S. 186, 195-96 (2003). The 1976 Act aligned with the Berne Convention by granting protection for life of the author plus fifty years. Now that copyright lasts well over one hundred years, the generation that grew up around the origination of a copyrighted good or service will never get the chance to use its expressive qualities for their own works.

144 Id. Under the 1976 Act, these works received seventy-five years of protection.

145 Helfand, supra note 30, at 629.

146 Sprigman, supra note 29.

147 Id; see also Samuelson, supra note 4, at 746. Mickey Mouse first appeared in the 1928 cartoon short "Steamboat Willie." The copyright in the cartoon, and also the character, was due to 
Eric Eldred offered free access to public domain works online and filed a challenge to the statute along with several other parties interested in public domain works. ${ }^{148}$ Eldred argued that Congress had exceeded its power to grant copyrights for "limited times" in order to "promote the Progress of Science," but the Court held that Congress did not exceed its grant of power because the term of protection was not perpetual and therefore was "limited." 149 The Court also gave deference to Congress and found that the Constitution left it to Congress to implement an intellectual property regime as it saw best to serve the purposes of commerce and the Copyright Clause. ${ }^{150}$ Eldred also argued that allowing the CTEA to pass would be opening the door for perpetual copyrights by letting Congress constantly create more copyright extensions. ${ }^{151}$ The Court found otherwise, stating that nothing in the act was attempting to create a perpetual copyright. ${ }^{152}$

In the end, the Court allowed Congress to extend the term of copyright protection twenty years for both future works and retroactively. ${ }^{153}$ This granted an extended shield of protection to all comic book characters as well. All the most popular characters, some dating back to the late 1930s, ${ }^{154}$ now will be privately owned for a further period of time. This

expire in 2003. Now Mickey is protected until 2023. Disney was also going to lose the rights to Winnie the Pooh, who was created in 1924 and would have entered the public domain in 1999 (now 2019). Both characters are valued at $\$ 8$ billion each. See Marvin Ammori, The Uneasy Case for Copyright Extension, 16 HARV. J.L. \& TECH. 287, 292 (2002). Disney lobbying for copyright extensions is ironic considering many of its films are stories that have fallen into the public domain, including "Frozen," "Snow White”, "Sleeping Beauty”, "Beauty and the Beast”, "The Little Mermaid”, and "The Hunchback of Notre Dame."

148 Sprigman, supra note 29. Eldritch Press can be visited at http://www.eldritchpress.org/.

149 Eldred v. Ashcroft, 537 U.S. 186, 199 (2003). The Court also noted that Congress has applied copyright protection extensions retroactively since the first Copyright Act. Id. at 200-04.

150 Id. at 205-08.

151 Id. at 208.

152 Id. at 209. The Court also distinguished between several cases Eldred used to try to establish that extending copyright protection went against the promotion of science and copyright's requirement of originality. Id. at 210-17. Eldred's last argument was that the statute was a content-neutral regulation that was subject to heightened scrutiny under the First Amendment, but the Court found First Amendment scrutiny to be unnecessary because Congress had not altered the traditional contours of copyright. Id. at 218-21. The Court emphasized that the Copyright Act contains built-in First Amendment protection in the idea/expression dichotomy and fair use. Id. at 219-20.

153 See David E. Shapley, Congressional Authority over Intellectual Property Policy After Eldred v. Ashcroft: Deference, Empty Limitations, and Risks to the Public Domain, 70 Alb. L. Rev. 1255 (2007).

154 Superman was first published in 1938. Superman, WIKIPEDIA, http://en.wikipedia.org/wiki/Superman (last visited Mar. 8, 2014). Batman was first published in 1939. Batman, WIKIPEDIA, http://en.wikipedia.org/wiki/Batman (last visited Mar. 8, 2014). With the ninetyfive-year protection from the CTEA, these characters are poised to enter the public domain in 2033 and 2034, respectively. Without the CTEA, these characters would have lost copyright protection in 2013 and 2014. 
allows copyright owners to continue to profit off their characters while limiting the availability of the character to the rest of the market and the public.

\section{PART II: MARVEL AND DC DO NOT CREATE A DUOPOLY EVEN THOUgH THE STUdIOS BLOCK THE MOST POPUlAR COMIC BOOK CHARACTERS IN THE FILM INDUSTRY}

The acquisition, licensing, and enforcement of intellectual property rights frequently requires attention to antitrust laws, which govern agreements or practices that put a restraint on trade. ${ }^{155}$ Antitrust laws are used to prevent the monopolization of an idea or product, which is when an individual or corporation holds a dominant share of a properly defined relevant market. ${ }^{156}$ Thus, while antitrust law penalizes monopolies to allow room for competition, IP law grants monopolies as rewards for innovation. ${ }^{157}$

Most antitrust issues involve patent disputes, rather than copyright disputes, because patents confer stronger protection against infringement. ${ }^{158}$ Patents can also involve horizontal agreements, where competitors who make the same product collude with each other to control prices or block others from entering the market. ${ }^{159}$ Patent rights are, therefore, enforced most often against competitors in the same market. ${ }^{160}$ Copyrights, on the other hand, are often enforced against would-be buyers rather than competitors because copyrights can only be infringed when a defendant copies a plaintiff's work, and a competitor can make a substitute for the work without copying it. ${ }^{161}$ Copyrights often involve vertical agreements, where firms along the supply chain of a product collude to provide benefits for each other. ${ }^{162}$ Horizontal agreements between patent owners are more dangerous than vertical agreements of copyright owners because "[t]he antitrust risks of vertical agreements are significantly less than the risks of

155 Edward G. Biester III, Ground Rules and Hot Topics in Antitrust and Intellectual Property, 228-JUN N.J. LAW. 18, 18-19 (2004).

156 Herbert Hovenkamp, Is Pepsi Really a Substitute for Coke? Market Definition in Antitrust and IP Response: Markets in IP and Antitrust, 100 GEO. L.J. 2133, 2157 (2012); see Walker Process Equip., Inc. v. Food Mach. \& Chem. Corp., 382 U.S. 172, 176-78 (1965).

157 Sunny Woan, Antitrust in Wonderland: Regulating Markets of Innovation, 27 TEMP. J. SCI. TECH. \& ENVTL. L. 53, 58 (2008).

158 Bruce Abramson, Intellectual Property and the Alleged Collapsing of Aftermarkets, 38 RUTGERS L.J. 399, 405 (2007).

159 Herbert Hovenkamp, et al., Anticompetitive Settlement of Intellectual Property Disputes, 87 MinN. L. REV. 1719, 1736 (2003).

$160 \quad I d$.

161 Id. at 1736-37.

162 Id. at 1737. 
horizontal agreements.”"163

The mergers of WB with DC and Disney with Marvel are vertical agreements rather than horizontal agreements. The movie studios and comic book publishers do not compete in the same market. One could characterize that a competition could exist because they deal with characters in different forms of media, but this analysis fails because the products of a movie studio and comic book publisher are not substitutes. ${ }^{164}$ If the price of Disney products were to go up or become unavailable, their customers would not go to Marvel as a substitute because the two serve different markets. The relationships are vertical agreements because the acquisition of the comic book publishers saves the film studios the costs of acquiring the publisher's properties for future use. ${ }^{165}$

One of the goals of this article is to identify the market power that each film studio has in the comic book movie genre. Defining a company's market power is part of an antitrust issue analysis of whether the company or an agreement between companies is anticompetitive. Market power may be demonstrated either by direct evidence of injury to competition inflicted by a company's market power or, more commonly, through circumstantial evidence. ${ }^{166}$ "To demonstrate market power circumstantially, a plaintiff must: (1) define the relevant market, (2) show that the defendant owns a dominant share of the market, and (3) show that there are significant barriers to entry and show that existing competitors lack the capacity to increase their output in the short run.”167

A. Scope of the Relevant Market for the Film Industry is Broad, but Scope of the Comic Book Genre is Based on Character Popularity

Defining the relevant market for the film industry, or even just the genre of comic book films, poses a challenge. The film industry does not set the prices for the tickets consumers purchase to see movies, so the industry has no power over the price of its own products. ${ }^{168}$ Price is not indicative of the market because the price of a movie ticket for different films is the same within a movie theater. ${ }^{169}$ Studio executives struggle to

\footnotetext{
163 Id.

164 See Deraiche, supra note 12, at 17-18.

165 See id. at 19

166 Rebel Oil Co. v. Atl. Richfield Co., 51 F.3d 1421, 1434 (9th Cir. 1995).

167 Id.

168 Jeff Tyson, How Movie Distribution Works, How STUFF WORKS, http://entertainment.howstuffworks.com/movie-distribution2.htm (last visited Mar. 8, 2014).

169 See Derek Thompson, Why Do All Movie Tickets Cost the Same?, THE ATLANTIC (Jan. 3, 2012, 12:59 PM), http://www.theatlantic.com/business/archive/2012/01/why-do-all-movie-tickets-costthe-same/250762/.
} 
find what type of movie can bring in an audience while staying on a low budget because they have no control over ticket prices. ${ }^{170}$ The competition is between each film rather than a single film against the entire market. ${ }^{171}$ So if an infringement does occur, the market would not be the entire film industry or even the comic book genre of films.

Because Disney and WB have exclusive rights to Marvel and DC characters, each studio is its own market for them. While Disney and WB will have exclusive use over the most popular comic book characters, they each also will have their own monopoly on a large number of these characters. If an infringer copies a Marvel character in a film, the infringer is not harming WB, but rather only Disney because the character would be a substitute for a Marvel character and not a DC character. The market is so narrow that it either harms only Disney/Marvel or WB/DC. Thus, harm done to one studio will not necessarily harm the other, so substitution issues become complicated.

The market for the film industry is further complicated by the fact that it has relatively high production costs, but can see little return on its investment because movies can be downloaded illegally online. ${ }^{172}$ But these "onerous front-end investments" do not deter competition because the film industry is not a business "dependent on a scarce commodity" and several blockbuster films come out each year. ${ }^{173}$ Therefore, the film industry's real power to make money comes from excluding others from seeing its products rather than excluding others from making comic book films. ${ }^{174}$ A studio's goal is then to provide the greatest value to a film so more people will want to see it but exclude people from seeing the movie unless they pay. ${ }^{175}$ The more people who pay to see a movie, the more money the movie will make and the more profit the studio will receive. The value of the film industry's products comes from the entertainment value of the movies produced, which stems from the popularity of the comic book character for comic book films. The popularity of the character is therefore

170 See Adam Davison, How Does the Film Industry Actually Make Money?, N.Y. TIMES, (June 26, 2012), http://www.nytimes.com/2012/07/01/magazine/how-does-the-film-industry-actually-makemoney.html.

171 See id.

172 “X-Men Origins: Wolverine,” which cost over \$100 million to make, was leaked online a month before its release and was watched more than 4.1 million times. Greg Sandoval, Will 'Wolverine' Benefit from (Bit)Torrent of Publicity?, CNET (May 1, 2009, 1:40 PM), http://news.cnet.com/83011023_3-10231922-93.html; see also Simmons, supra note 14, at 299-301. The effect of losing money from illegal downloads is only for blockbuster films while smaller movies actually benefit from piracy. Ernesto, Megaupload Shutdown Hurt Box Office Revenues, TorRENT FreAK (Nov. 24, 2012), https://torrentfreak.com/megaupload-shutdown-hurt-box-office-revenues-121124/.

173 United States v. Syufy Enters, 903 F.2d 659, 667 (9th Cir. 1990).

174 See Hovenkamp, supra note 156, at 2139.

175 See id. 
an important factor in deciding whether to make a comic book film because it can relate directly to how much money the movie may make.

\section{B. Disney and WB Have Dominant Shares of the Comic Book Film Market}

The market for comic book movies is based upon the featured characters since it is the popularity of those characters that is the main draw for moviegoers. ${ }^{176}$ But the most popular comic book characters are being blocked from potential use in the film industry because WB and Disney own them. ${ }^{177}$ Comic characters can be licensed to studios to make a film, such as Spider-Man being licensed to Columbia Pictures and X-Men being licensed to Twentieth Century Fox. ${ }^{178}$ But WB has always had a hand in making DC comic book character films because the studio owns the comic book publishing company. ${ }^{179}$ Marvel was not linked with a studio until it opened its internal studio to make films based off of its own characters, but now all of Marvel's characters that are not still licensed out to other studios fall under Disney. ${ }^{180}$

These vertical agreements show a dominant share of the market for comic book characters because WB and Disney can now prevent others from using DC and Marvel characters. ${ }^{181}$ Having the two studios control the great majority of characters constricts the comic book film market because more films are made when more studios have access to the characters. $^{182}$ Other characters are available from other comic book

176 See Benjamin A. Goldberger, How the "Summer of the Spinoff" Came to Be: The Branding of Characters in American Mass Media, 23 Loy. L.A. ENT. L. REV. 301, 302 (2003) ("Although others aspects of a work can be reused to create new works, it is the character that is most portable and most profitable. Characters such as James Bond, Hercule Poirot, and even Bart Simpson transcend any one work in which they appear. The thing that makes them so valuable is that they can appear over and over again in a variety of media. With these brand name characters, the ability to use them in derivative works is even more valuable than the right to sell any one particular work.”); see also Zahr K. Said, Fixing Copyright in Characters: Literary Perspectives on a Legal Problem, 35 CARDOzo L. REv. 769, 771-72 (2013) ("Creating enduring characters increases the likelihood that audiences will buy subsequent works. Subsequent works in which characters star may change, but the characters themselves often remain effectively the same. Characters' value to authors derives in substantial part from their capacity for potential perpetual reuse in new works.”).

177 See supra notes 19-25 and accompanying text.

178 See supra note 15 and accompanying text.

179 See supra notes 23-25 and accompanying text.

180 See supra notes $15,19-21$ and accompanying text.

181 The vertical agreements are not giving too much power to the studios in the market share of all films from movie studios because the percentages are more evenly distributed. Studio Market Share, BOX OFFICE MOJO, http://www.boxofficemojo.com/studio/?view=company\&view2=yearly\&yr=2012\&p=.htm (last visited Mar. 8, 2014).

182 See Citizen, Marvel Studios Doesn't Own the Rights to All of Their Characters... and 
publishers, but the majority of characters in the industry come from Marvel and DC because those two publishers have more than an eighty percent market share in the comic publishing industry. ${ }^{183}$ But even though these two companies have a high market share, that does not lead to monopoly concerns without more evidence. ${ }^{184}$ Though the film studio benefits from the comic book publishing company to the exclusion of other film studios, this type of vertical agreement does not meet the third requirement of finding an anticompetitive market power.

\section{Other Film Studios Have No Barriers to Entry or Lack of Capacity to Enter the Comic Book Film Genre Because There are Substitutes for the Most Popular Characters}

The vertical agreements created between WB/DC and Disney/Marvel are not a duopoly ${ }^{185}$ over the most popular comic book characters even though they are blocked from the rest of the film industry because there are ample substitutes and other studios have the capacity to use these

That's a Good Thing, COMIC BooK Movie (July 18, 2013), http://www.comicbookmovie.com/avengers/news/?a=83593. Starting from the popularity of comic book films from 2000, thirty movies based on Marvel characters have been released in theaters by the end of 2013 with another seven films planned until the end of 2015. List of Films Based on Marvel Comics, WIKIPEDIA, http://en.wikipedia.org/wiki/List_of_films_based_on_Marvel_Comics (last visited Mar. 8, 2014). These films have been made by several different studios including Marvel Studios, Universal Studios, Twentieth Century Fox, and Columbia Pictures. Id. Meanwhile, during the same time period only nine movies based on DC characters have been released in theaters with only one more film slated for the future. List of Films Based on DC Comics, WIKIPEDIA, http://en.wikipedia.org/wiki/List_of_films_based_on_DC_Comics (last visited Mar. 8, 2014). All of these films were made by WB. Id. And, for some reason in this same time period, WB has made more than twenty animated films based on DC characters. $I d$. Note that if the characters are split among several studios instead of one, it is unlikely for a shared cinematic universe to exist. See infra note 301.

183 Richard Siklos, Spoiler Alert: Comic Books are Alive and Kicking, CNN MONEY (Oct. 13, 2008, 12:09 PM), http://money.cnn.com/2008/10/10/news/companies/siklos_marvel.fortune/; see also supra note 11. Marvel will now be getting an even bigger share of the comic book market because Disney has pulled its comic book publishing of Disney characters from another comic book publishing company and gave it to Marvel. Ricky Brigante, Disney Ending Partnership with BOOM Studios, Future of 'Disney Afternoon' Comics Uncertain, INSIDE THE MAGIC (Aug. 8, 2011), http://www.insidethemagic.net/2011/08/disney-ending-partnership-with-boom-studios-future-of-disneyafternoon-comics-uncertain/. Disney will also have Marvel begin publishing Star Wars comics, which have been published by Dark Horse Comics for the past twenty years. Albert Ching, 'Star Wars' Comics Move to Marvel in 2015 , COMIC BooK RES. (Jan. 3, 2014, 10:02 AM), http://www.comicbookresources.com/?page=article\&id=50069.

184 Oahu Gas Serv., Inc. v. Pac. Res., Inc., 838 F.2d 360, 366 (9th Cir. 1988), cert denied., 488 U.S. 870 (1988) ("A high market share, though it may ordinarily raise an inference of monopoly power ... will not do so in a market with low entry barriers or other evidence of a defendant's inability to control prices or exclude competitors.”).

185 A "duopoly" has been defined as "[a] market in which there are only two sellers of a product.” BLACK’s LAW DiCTIONARY 577 (9th ed. 2009). 
substitutes. $^{186}$ A court would likely balk at a studio claiming WB and Disney had a duopoly over the most popular comic book characters because there are hundreds of other comic book characters not owned by DC or Marvel that have the potential to make an entertaining movie. ${ }^{187}$ One could question "whether there could ever be barriers of entry in an industry that require[s] only imagination to create a product" because another studio can also create a new character and publish it to the world. ${ }^{188}$ Of course, none of these comic book characters have the same name brand power as the others, and that popularity is what a movie studio is hoping to use to make a profit off the film. ${ }^{189}$

The most popular comic book characters are essentially blocked from the rest of the film industry because the characters are each owned by a single film studio. Other studios are now left with the choice of either using independent comic book characters that do not have the same popularity as Marvel and DC characters or creating a new comic book style character with a unique background and story. ${ }^{190}$ While Marvel and DC characters are

186 The film studios can dominate the market share for comic book films until another studio makes a film based off a lesser known comic book that turns out to be successful. Thus, it is not just having market share that counts, but also being able to maintain that market share. See Oahu Gas, 838 F.2d at 366 .

187 The concept of the market refers to the range of inter-firm rivalry and the degree of substitution between these rivals rather than the power each of them holds. See Hovenkamp, supra note 156, at 2137. The impact can be assessed only by examining the range of alternatives that the market offers. See id. at 2145. There are other comic book publishers besides Marvel and DC, such as Dark Horse, Image, and Oni Press. These other publishers have comic books that can be made into movies as well, such as Red, Hellboy, Sin City, The Crow, Spawn, and Scott Pilgrim.

188 See Deraiche, supra note 12, at 19.

189 The ironic twist is that other studios did have the chance to use Marvel and DC characters before WB and Disney took exclusive control over them. Michael Uslan, an entertainment lawyer who loved comics his entire life, spent ten years trying to get the original Batman movie made because no studio was interested. Michael Uslan, The Boy Who Loved BATMAN: A Memoir, 181-200 (2011). After the success of the Batman films, Marvel began licensing out its characters to several studios in hopes to ride the wave of comic book film success. See supra note 14 and accompanying text. But it took nearly a decade for some of these characters to hit the silver screen while some of them never did and the rights reverted back to Marvel, where the comic book publishing comic took it upon itself to make movies based of its characters. Popular Marvel characters that were available to other studios before reverting back to Marvel include Hulk, Blade, Punisher, Thor, Iron Man, and Daredevil. The first Hulk film was actually made by Universal Studios before the rights reverted back to Marvel so that it could include the character in The Avengers. As for the characters that are currently still licensed out to other studios, Disney is planning on getting those characters back under its name soon. Marvel Studios' President Kevin Feige said that the contracts for all the licensed characters are all very specific and there may be a time soon when they can revert. Ben Mortimer, The Avengers European Premiere Interview: Marvel President Kevin Feige Gives Studios Update, HEY U GuYs (Apr. 19, 2012), http://www.heyuguys.co.uk/the-avengers-european-premiere-interview-producer-kevin-feige-givesmarvel-studios-updates/.

190 See United States v. Microsoft Corp., 253 F.3d 34, 64 (D.C. Cir. 2001) (“[A]lthough Microsoft did not bar its rivals from all means of distribution, it did bar them from the cost-efficient ones.”). 
currently limited to two film studios, the characters may become available again either by entering the public domain once the character's copyright protection expires or by the author of the character terminating his grant of rights given to the comic book publishing company. But there are several impediments to these events happening. Characters may continue to receive copyright protection as copyright duration is subject to change because companies fear the public domain and will lobby for extensions. Companies will also hold authors in court for years over termination lawsuits.

\section{PART III: COPYRIGHT DURATION SHOULD NOT BE EXTENDED BECAUSE Public DOMAIN WORKS CAN STILl Be PROTECTED AND TERMINATION \\ Rights SHOUld BE MAde EASIER to EXERCise BECAUSE THEy CREATE INCENTIVES FOR AUTHORS TO DISTRIBUTE THEIR WORK}

\section{A. Companies Should Not Fear the Public Domain Because Public Domain Works Can Still Have Limited Protections While Not Being Underused, Overused, or Tarnished}

The Constitution says that copyright protection will be for a limited time, ${ }^{191}$ and the Supreme Court has interpreted the term "limited" to mean as long as the term of protection is not perpetual. ${ }^{192}$ But with copyright protection now at life of the author plus seventy years, the term "limited" is beginning to become stretched. The standard justification for copyright protection is the incentive to create and the primary argument for extending the copyright term would be that the incentive to create will be increased. ${ }^{193}$ Other arguments include that works without protection will be underutilized because there will be no incentive to protect them, works in the public domain will be overused, and poor quality versions of the work will be made in the public domain that will tarnish the value of the underlying work. ${ }^{194}$ These arguments were later used by Congress ${ }^{195}$ and the Supreme Court $^{196}$ to justify the passage of the CTEA, but there is no evidence to support these claims.

191 U.S. CONST. art. I \& 8.

192 Eldred v. Ashcroft, 537 U.S. 186, 199-204 (2003).

193 See supra note 30 and accompanying text.

194 Christopher Buccafusco \& Paul J. Heald, Do Bad Things Happen When Works Enter the Public Domain?: Empirical Tests of Copyright Term Extension, 28 BERKELEY TECH. L.J. 1, 3 (2013).

195 See H.R. Rep. No. 105-452, at 4 (1998) (stating that retroactive extension would "provide copyright owners generally with the incentive to restore older works and further disseminate them to the public”).

196 See Eldred, 537 U.S. at 207 (finding that Congress "rationally credited projections that longer terms would encourage copyright holders to invest in . . p public distribution of their works”). 
[Vol. 9:405

Extension of already existing copyrights does not promote progress or provide incentives because already existing works cannot be created anew. ${ }^{197}$ "Congress is not empowered merely to provide copyright holders with an additional boon - that is not 'progress,' but corporate welfare."198 Congress could have offered "the quid of an extended copyright in exchange for the quo of the copyright holder taking steps to preserve the copyrighted work ....."199 But there is no such quid pro quo as the statute is a giveaway of extended protection to copyright owners. ${ }^{200}$ As for new works created after the act, the incentive is likely very little as the author of the work will no longer be around to reap the benefits of the product. ${ }^{201}$

Works without copyright protection will not be under-utilized because they will be used as often as protected works. The argument is based on the fact that without protection anyone can use the work and the copyright owner will not be able to recoup his investment costs. ${ }^{202}$ Without a method for recouping investment costs, "commercializers will have inadequate incentives to continue production and distribution of older works." ${ }^{203}$ For these reasons, works in the public domain will be underproduced. But evidence points out that works in the public domain are just as utilized as works with copyright protection. Researchers found that public domain works in print outnumbered copyrighted works in print in a study done to

197 Samuelson, supra note 4, at 746 ("It was logically infeasible for a twenty-year term extension to provide incentives to create new works that were already in existence. Even applied prospectively, the CTEA could have no more than negligible incentive effects on authors contemplating whether to create new works.”); see also Jennifer Jenkins, In Ambiguous Battle: The Promise (and Pathos) of Public Domain Day, 2014, 12 DuKE L. \& TECH. REV. 1, 6-7 (2013). These negligible incentive effects do not outweigh the cost imposed on society by limiting the public domain because the majority of copyrighted works have relatively short commercial lives and long terms "impose transaction costs on others, provide windfalls to rights holders, and inhibit the creation of new works based upon expression from earlier works...." Samuelson, supra note 4, at 747. A Congressional Research Service study suggested that only two percent of works between fifty-five and seventy-five years old retain commercial value. Eldred v. Ashcroft, 537 U.S. 186, 248 (2003) (Breyer, J., dissenting). Even under the renewal term for copyright, eighty-five percent of all registered copyrights were not renewed and that figure was ninety-three percent for book copyrights. James Boyle, We Need to Start Seeing Other Futures..., HUFFInGTON POST (Jan. 14, 2014, 1:25 PM), http://www.huffingtonpost.com/jamesboyle/copyright-week_b_4596424.html.

198 Sprigman, supra note 29.

199 Id.

200 Id

201 See Thomas F. Cotter, The Procompetitive Interest in Intellectual Property Law, 48 WM. \& MARY L. REV. 483, 532 (2006) ("The likelihood that this extension serves a public purpose with respect to future works is slim, given the small present value of an additional twenty years' worth of protection in the distant future; the likelihood it serves a public purpose with respect to existing works is even slimmer, though theoretically possible.”).

202 Buccafusco, supra note 194, at 13.

203 Id. at 14. 
measure the percentage of best seller books in older works. ${ }^{204}$ Another study tracked the use of public domain songs in films and found that public domain songs were exploited as equally as copyrighted songs. ${ }^{205}$ Many films are based on public domain stories ${ }^{206}$ and even comic book characters in the public domain have seen new life, ${ }^{207}$ which goes against the theory of under-utilization. Therefore, "keeping older works under copyright frequently frustrates, rather than promotes, their maintenance and dissemination." 208

The "tragedy of the commons" argument that public domain works will be overused fails because the works will not be used so much as to deplete their value. This theory rests on the assumption that the value of a work is finite and exhaustible, and that the work will be exploited until its value is diminished. ${ }^{209}$ According to this assumption, a creative work has an increasing value only up to a certain number of uses in a given period, and once that level is met the work's value diminishes, so a copyright owner has the incentive to not over-exploit the work. ${ }^{210}$ This argument fails because studies suggest that repeated exposure to a work may actually increase its attractiveness. ${ }^{211}$ If a song or comic book character is considered to have a maximum level of exploitation, then why are popular songs played the most ${ }^{212}$ and comic book characters utilized in a variety of

204 Paul J. Heald, Property Rights and the Efficient Exploitation of Copyrighted Works: An Empirical Analysis of Public Domain and Copyrighted Fiction Bestsellers, 92 MinN. L. REV. 1031, 1046-50 (2008) (ninety-eight percent of the bestsellers from the public domain were in print compared to only seventy-two percent of copyrighted bestsellers of older works).

205 Paul J. Heald, Does the Song Remain the Same? An Empirical Study of Bestselling Musical Compositions (1913-1932) and Their Use in Cinema (1968-2007), 60 CASE. W. RES. L. REV. 1, 19 (2009).

206 See supra note 147 and accompanying text. Snow White is in the public domain despite Disney having a copyright in its animated film, and there have been several other Snow White movies (with two released in 2012). See infra note 280.

207 The character, Moon Girl, entered the public domain and was not seen again until 2010. Moon Girl, WIKIPEDIA, http://en.wikipedia.org/wiki/Moon_Girl (last visited Mar. 8, 2014).

208 Jenkins, supra note 197, at 7.

209 Buccafusco, supra note 194, at 16.

$210 \quad$ Id. at 17.

211 See Robert B. Zajonc, Attitudinal Effects of Mere Exposure, 9 J. Personality \& Soc. PsychOL. 1, 1 (1968) ("[M]ere repeated exposure of the individual to a stimulus is a sufficient condition for the enhancement of his attitude toward it.”). This relates as a direct example for the film industry because the movie "It's A Wonderful Life" was considered a failure, but because it entered the public domain and was aired on several channels during the holidays for years, it is now considered a holiday classic. Why Wonderful Life Comes but Once a Year, SLATE (Dec. 21, 1999, 10:37 PM), http://www.slate.com/articles/news_and_politics/explainer/1999/12/why_wonderful_life_comes_but_on ce_a_year.html.

212 Though the most popular songs are now caught on YouTube or Twitter before they hit the radio. Ben Sisario, The New Rise of a Summer Hit: Tweet It Maybe, N.Y. Times (Aug., 21, 2012), http://www.nytimes.com/2012/08/22/business/media/how-call-me-maybe-and-social-media-areupending-music.html?_r=0. 
media for generations? ${ }^{213}$ It is because if something has value, even copyright owners will exploit that value until it is theoretically depleted in order to gain the most profit.

The tarnishment theory behind not letting works enter the public domain fails because a poor quality version of the work does not affect the judgment of consumers about the quality or value of the original work. The idea behind this argument is that creative works can lose their value through inappropriate uses. ${ }^{214}$ The number one example for this argument is that of porn parodies. But this fails because in a time when comic book character films are as popular as ever, an entire pornography studio has been set up for years producing porn parodies of these characters. ${ }^{215}$ Vivid Superhero has created porn parodies of Batman, Superman, Spider-Man, and The Avengers. ${ }^{216}$ Another argument based off the tarnishment theory is that poor quality productions of the work will debase the value of the original. But this argument also fails because there have been poor quality productions of copyrighted works, such as the film "Eragon," ${ }^{217}$ yet the original work is still popular. ${ }^{218}$

For the foregoing reasons, copyright duration should not be extended anymore. The arguments used by the Supreme Court and Congress fail a reasonable analysis because there is no evidence to back them up. Extending copyright duration for creative works fails for comic book characters because the characters are all heavily exploited while still under copyright protection and when they enter the public domain, they can still be exploited. ${ }^{219}$ Fears that there will be no incentives to protect the

213 Superman first appeared in 1938 and the character's film franchise was recently rebooted in 2013. Between then and now, you can find thousands of comic books, newspaper strips, toys, cartoons and other Superman merchandise as well as the dozens of character-related movies and television shows. This amount of exploitation is for just one of hundreds of popular comic book characters. These characters are most likely going to be exploited even after copyright protection ends. See infra Section IV. Where exactly does this maximum level of exploitation fit in?

214 Buccafusco, supra note 194, at 17-18.

215 See supra note 129 and accompanying text.

216 Vivid Entertainment Announces New Superhero Imprint, VIVID (May 2, 2010), http://vivid.com/news/2010-05-10/vivid-entertainment-announces-new-superhero-imprint/. (Warning: this is an adult NSFW website).

217 While the books have received favorable reviews, with the latest coming out in 2011, the 2006 movie was universally panned. Eragon, ROTTEN TOMATOES, http://www.rottentomatoes.com/m/eragon/ (last visited Mar. 8, 2014).

218 This has happened in the comic book character genre as well. Films such as "Superman Returns" and "X-Men: The Last Stand" received generally unfavorable reviews, which eventually led to the studios focusing on reboots or spin-offs instead of returning to the disliked continuity.

219 Character owners can still use derivative works to protect characters that have entered the public domain or had their grant of rights terminated. New, protectable expression added to the character in derivative works do not fall into the public domain with the original character story and are not a part of the author's original grant of rights, thus those aspects of the character are still a protected derivative 
characters more or that they will be overused/misused are just fears that copyright owners will not be able to make as much money off the work as they used to. Copyright duration should, therefore, stay as is or should create a structure where works enter the public domain after an author's death, unless the author's heirs register their interests with the Copyright Office for full copyright duration. ${ }^{220}$

B. Termination Rights Should Be Made Easier to Exercise Because Companies Can Still Exploit the Character in Derivative Works and Can Exhaust an Author's Right to Terminate in Renegotiated Agreements

Copyrighted works are not valuable for an author without a means of exploiting the work, so it is common for an author to assign the copyright to a publisher. ${ }^{221}$ "The central problem with this arrangement is in the difficulty of determining the value of a work before its publication. . . [u]nlike real property or personal property, it is nearly incapable of determining the accurate monetary value of an expressive work prior to its exploitation." ${ }^{222}$ Due to this difficulty, an author may assign the copyright to a work for much less than the creative work's real value. ${ }^{223}$ Termination rights thus protect the works of authors from being exploited by large companies and corporations. It allows authors to renegotiate deals based off of the real value of their works after the company has exploited the work for several years and the real value of the work is easier to determine. But the real value of the work is undetermined at the time of the deal for both sides because a company may secure copyrights to a number of works that prove unsuccessful and may well pay the author more for the work than it is actually worth. ${ }^{224}$ A company would believe that it should receive the full

work. Helfand, supra note 30, at 655 n.181. Comic book characters evolve and change over time by changing costumes, names, or having another character adopt the hero name altogether. Id. These character evolutions are still protectable even if the character's original work is no longer afforded copyright protection. Id. This example is like the decision made in the Sherlock Holmes case, where the character entered the public domain but several of the character's stories still remain in copyright under the incremental expression test. Eriq Gardner, Sherlock Holmes: Judge Declares Popular Detective in Public Domain, The Hollywood ReP. Esquire (Dec. 27, 2013, 11:41 AM), http://www.hollywoodreporter.com/thr-esq/sherlock-holmes-judge-declares-popular-667755. Only the additions to the character from the books after 1923 are copyrighted while the original version of the character is free for the public. Id. For more on the incremental expression test, see Section IV.A.

220 Eriq Gardner, U.S. Congressmen Told About 'Next Great Copyright Act' at Hearing, THE HOLLYwOOD REP. ESQUiRE (Mar. 20, 2013, 3:51 PM), http://www.hollywoodreporter.com/thr-esq/uscongressmen-told-next-great-430091.

221 Bales, supra note 38, at 663.

222 Id.

223 Id. at 663-64.

224 Id. at 664 . 
benefit of the work without the fear of termination after successfully exploiting the work. But the author should be allowed to share some of the benefits as a reward for the initial creation and as an incentive to create more works.

Termination rights benefit authors because it gives them extra bargaining power when the large company or corporation usually has the upper hand in copyright transfers. ${ }^{225}$ When Jerry Siegel and Joe Shuster sold the rights to the Superman character to DC for \$130 in 1938, "no one could have foreseen that Superman would remain a comic mainstay for the next 80-plus years, be the star character in several major motion pictures, and otherwise anchor a franchise worth in excess of $\$ 1$ billion."226 Termination rights provide an incentive for authors to create and disseminate new works because they will have a chance of renegotiating on the work's real value. ${ }^{27}$ This also allows for renegotiating in the face of the company exploiting the work in new technologies that were unavailable during the initial deal. ${ }^{228}$

An argument against termination rights is that allowing authors or heirs to recapture the rights to a creative work is inconsistent with promoting certainty of copyright ownership because of the unique way that companies develop works once they own them. ${ }^{229}$ "[W]hen an author creates a fictional character and sells it to a media company, the media company adds new original material to the character over the course of hundreds of successive comic book issues, films, or television episodes, thereby developing the character's history, personality, beliefs, and mission." 230 Authors and heirs thus receive a "substantial windfall" because the character only shares nominal ties to the author's original creative investment. $^{231}$ This argument fails because an author's initial creative investment created the bedrock upon which further creative expression is only added to, and also because companies have a variety of compromises

225 See generally supra notes 40-48 and accompanying text.

226 Weiman, supra note 37 , at 4.

227 Lydia Pallas Loren, Renegotiating the Copyright Deal in the Shadow of the "Inalienable" Right to Terminate, 62 FLA. L. REV. 1329, 1349 (2010). This argument only works for the $\S 203$ termination right because it is the right for new works. The argument for the $\S 304$ termination right is that it grants in the author the chance to use the renewal term if that was contracted away and that the termination right applies to an unanticipated extension in the duration of copyright that benefitted the owner of the copyright, not the author. Id. at 1351-52.

228 Id. When Siegel and Shuster signed away their rights to Superman for comic book adaptation in 1938, they did not know they would be signing away their rights to the characters in unforeseen technologies such as television or the Internet.

229 See Vincent James Scipior, The Amazing Spider-Man: Trapped in the Tangled Web of the Termination Provisions, 2011 WIS. L. REV. 67, 70-72 (2011).

230 Id. at 72.

231 Id; see also Krueger, supra note 38, at 244-45. 
and exceptions that benefit them to the exclusion of the author.

One of the compromises courts have created is that agreements will often act as effectively exhausting the termination right when parties have entered into a subsequent agreement concerning a work subject to an existing copyright grant. "Where parties have renegotiated the terms of an assignment, and it appears that the result is substantially the same as it would have been had the author or heir terminated the grant and renegotiated a new one, a court may find that there has essentially been a de facto exercise of the statutory agreement."232 If the court finds that the termination right had vested at the time of the renegotiated agreement, and was thus a material aspect of the new agreement, then it will honor the renegotiated agreement over the author's claim of termination. ${ }^{233}$

The works-made-for-hire and derivative works exceptions also aid companies in spite of the termination rights of authors and heirs. If a creative work is made pursuant to the terms of an employment contract, then the copyright in that work vests in the employer. ${ }^{234}$ This exception lets companies own any of the work that others may make if the work was made for the company. ${ }^{235}$ The derivative works exception allows companies to continue to exploit derivative works based on the recaptured copyright and produced before termination. ${ }^{236}$ This lets companies only renegotiate for the copyrights to the original grant and not have to renegotiate about successful adaptations of the original work.

Issues regarding termination rights can be very fact specific as to whether the work was done for hire, or whether there was a renegotiated agreement. Companies fear losing out on a work that has been exploited successfully for many years and will use all their resources to find a way around the termination provision. While all copyright transfers are subject to termination rights, companies should not worry about every copyright transfer being terminated because the right will only be exercised for successful works that still have commercial power after thirty-five years. ${ }^{237}$ And with agreements signed in 1978 now ready for termination, this provision is going to become even more important over the next few years. $^{238}$ Termination rights should be easier to achieve for authors and

232 Bales, supra note 38, at 665.

233 Id.; see generally supra notes 113-115 and accompanying text. A renegotiated agreement was found in the Siegel and Shuster cases. See supra notes 106-107, 109-110 and accompanying text.

234 See supra note 49 and accompanying text.

235 Though this could lead to companies only hiring on a work-for-hire basis and the independent creation of comic books will become stagnant. Krueger, supra note 38, at 243-44.

236 See 17 U.S.C. §§ 203(b)(1), 304(c)(6)(a) (2011); see also supra note 51 and accompanying text.

237 Loren, supra note 227, at 1352-53.

238 See Eriq Gardner, How the Legal Fight Over 'Y.M.C.A.' Could Change the Music Industry, 
heirs, because being held up in court and wasting judicial resources on frequent, fact-specific inquiries is not a viable option for either party. And with the Ninth Circuit's holding in Siegel that a renegotiated agreement can be binding even if material terms have not been dealt with, ${ }^{239}$ it is easier for a company to claim that the termination right is invalid. The moral of the story is that termination rights are invaluable to an author and his heirs in renegotiating the terms of the original transfer of copyright, but the author needs to determine at the beginning whether the work is done for hire, and then be clear in negotiations about what terms are agreed upon.

\section{PART IV: THE FUTURE OF COMIC BOOK CHARACTERS: INCREMENTAL EXPRESSION AND TRADEMARK PROTECTION ISSUES FOR CHARACTERS IN THE PUBLIC DOMAIN OR RETURNED TO AUTHORS}

\section{A. The Incremental Expression Test Will Let Characters Gradually Enter the Public Domain so Derivative Works Can Continue to be Exploited}

The incremental expression test will determine what aspects of characters enter the public domain or return to the original author after termination, as well as what increments of expression to that character can continue to be exploited by companies. This test developed from the derivative works doctrine, where the character in a public domain work could be exploited, but subsequent works the character appeared in still under copyright protection could not. ${ }^{240}$ The subsequent works would be considered derivative works and the only protectable elements of it would be any additional original expression. ${ }^{241}$ In other words, the incremental expression added to the derivative work is still protectable, such as new character traits, but traits originating from the public domain or terminated work, though present in the derivative work, are not additional original expression and are thus not protected by copyright by the company.

THE HOLLYwOOD ReP. ESQUiRE (Aug. 17, 2011, 4:16 PM), http://www.hollywoodreporter.com/thresq/how-legal-fight-ymca-could-224469; see also Eriq Gardner, Rock Band Boston Involved in Copyright Termination Fight, THE Hollywood ReP. ESQUIRE (Mar. 21, 2013, 9:06 AM), http://www.hollywoodreporter.com/thr-esq/rock-band-boston-involved-copyright-430177.

239 Larson v. Warner Bros. Entm’t Inc., 504 Fed. App’x. 586, 587-88 (9th Cir. 2012). The court points out that this is only viable under California law, but this could become dangerous precedent for all forms of negotiations if other courts begin to agree with this opinion. Id.

240 Foley, supra note 73, at 935; see also Klinger v. Conan Doyle Estate, Ltd., 2013 U.S. Dist. LEXIS 180493, at *27 (N.D. Ill. Dec. 23, 2013).

241 Joseph P. Liu, The New Public Domain, 2013 U. ILL. L. REV. 1395, 1442-43 (2013). Whether a work is sufficiently original to warrant derivative copyright protection is another question that should be asked, but it is easy to assume original expression since the threshold for originality is low for visually depicted characters. Id. 
"The standard for analyzing fictional characters in derivative works was developed in litigation over the Amos ' $n$ ' Andy characters."242 In Silverman v. CBS Inc., ${ }^{243}$ a playwright sought to use the characters in a musical because radio scripts from before 1948 featuring the characters were in the public domain. ${ }^{244}$ CBS had properly maintained the copyrights in the post-1948 radio scripts as well as the television program featuring the characters. ${ }^{245}$ The court held that the playwright could use the characters since they were sufficiently delineated in the pre-1948 radio scripts, which were in the public domain. ${ }^{246}$ But the playwright was not allowed to use any further delineation of the characters contained in the post-1948 scripts and the television programs because those were still protected by copyright. $^{247}$

The incremental expression test has recently been used to hold Sherlock Holmes in the public domain even though several stories featuring the character are still protected by copyright. The characters were first introduced in 1887 and four novels as well as forty-six out of fifty-six short stories featuring the characters are in the public domain. ${ }^{248}$ The court held that where an author uses the same characters in a series of work, some of which are in the public domain, the public is free to copy story elements from the works. ${ }^{249}$ The public may use the story elements from the public domain works without a license, but may not use the increments of expression from derivative works still under copyright protection. ${ }^{250}$ The court defined increments of expression to include storylines, dialogue, characters, and character traits introduced in derivative works. ${ }^{251}$ Thus the characters from the public domain works are free to use, but the additional original expression (such as Holmes's retirement and Watson's second wife) are still protected by copyright. ${ }^{252}$

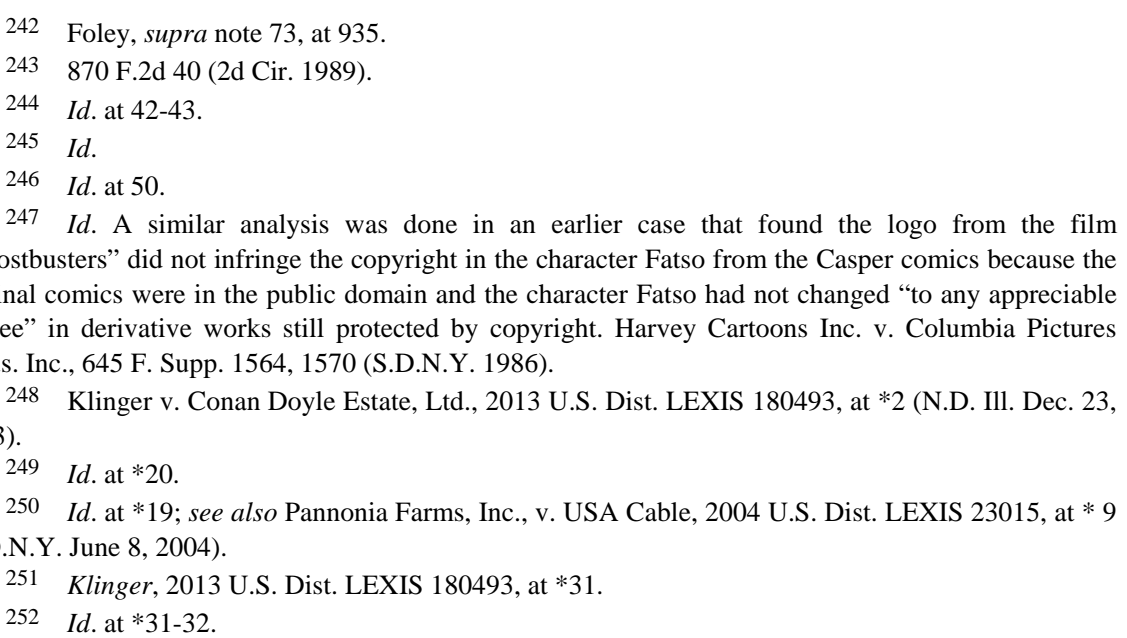


Characters that have gone through changes in different media will therefore have certain traits, characteristics, and depictions that will still be protected by copyright even though the characters themselves are either in the public domain or returned to the original author. In the Superman case that held Siegel had properly terminated the grant of rights to the character, the court did not determine the extent to which later iterations of the character were derived from the original. ${ }^{253}$ The incremental expression test would likely have been done if Siegel wanted to use the character in new works because his heirs would not have been allowed to use any expression that DC added to the character over the years. ${ }^{254}$ DC would be able to exploit all the derivative works that featured Superman, but would not be able to create any new works without permission from Siegel's heirs. The incremental expression test can also be used to gradually allow a character to enter the public domain and freely allow the use of additional expression added to that character as different depictions of the character lose copyright protection over time. ${ }^{255}$

B. Mark Owners Will Need to Show Secondary Meaning to Limit the Use of Public Domain and Terminated Characters in New Expressive Works Made by Another

Supposing that copyright duration is set so that works will soon enter the public domain and termination rights are easier to use for authors to retrieve rights to their characters, how can companies continue to exploit a character once they no longer have the rights to it? Trademark law will still protect certain uses of that character after it enters the public domain or is returned to an author. But, trademark law will have to be managed when used for a character that no longer has copyright protection because unfair competition and trademark dilution can essentially put a permanent ban on

253 Michael Cieply, Ruling Gives Heirs a Share of Superman Copyright, N.Y. TIMES (Mar. 29, 2008), http://www.nytimes.com/2008/03/29/business/media/29comics.html?_r=0. The court found that promotional material featuring Superman was not included in the termination, but held that this material did not give DC the rights to the character because the promotional material merely featured a strong man and did not have any of the character traits added to Superman from the later comics. Siegel v. Warner Bros. Entm’t. Inc., 542 F. Supp. 2d. 1098, 1126 (C.D. Cal. 2008).

254 The Siegels had recaptured the rights to his original abilities and origin, but not to many of the character's famous traits developed by DC, such as the ability to fly and the villain Lex Luthor. Kratzer, supra note 114, at 1163-65.

255 The original character can enter the public domain with different traits and depictions becoming free to use over time as those works with those new traits lose copyright protection. An author with a terminated character will not be able to use the additional traits or depictions until they enter the public domain because those traits were not a part of the grant of rights given to the company and therefore cannot be terminated back to the author. Use of public domain works that include incremental expression from copyrighted work will be found to infringe. See Warner Bros. Entm't. Inc. v. X One X Prods., 644 F.3d 584, 602-03 (8th Cir. 2011). 
marked characters that a company no longer exclusively owns. To determine whether the use of the character should be banned under trademark, a court must look at how the character is being used and if the character has secondary meaning.

Once a fictional character that "has been used expressively and indicatively" no longer receives protection due to entering the public domain or termination of a copyright grant, the character's indicative functions are doctrinally still subject to protection. ${ }^{256}$ "In effect, then, the fictional character becomes, like any other trademark logo or design, subject to the common law restrictions that apply to non-character marks. The owner will clearly want to prevent any unauthorized uses of the 'fictional character as a mark' which attempt to take advantage of its secondary meaning." ${ }^{257}$ This is especially true where the company will continue to use the character in copyrightable works even after the character is no longer copyrightable. ${ }^{258}$ Disney will likely attempt to extend the mark-based protection to unauthorized expressive uses of Mickey Mouse after it enters the public domain because the character is indicative of the Disney Company worldwide. ${ }^{259}$

When a marked character enters the public domain or has its copyright returned to the author, the character may still retain the goodwill of the mark's owner. "When a source has developed goodwill in its goods or services, perhaps for 50 or more years, the public relies on the mark for assurance of the same quality, thus supporting economic efficiency."260 Taking away the trademark of a character that enters the public domain or gets its copyright grant terminated "undervalues trademark's economic and

256 Helfand, supra note 30, at 657.

257 Id; see also Mattel, Inc. v MCA Records, Inc., 296 F.3d 894, 900 (9th Cir. 2002) (explaining that marks assume a role outside of trademark law and receive First Amendment protection when a mark transcends its identifying purpose and enters the public discourse to become an integral part of culture); see also Mattel, Inc. v. Walking Mountain Prods., 353 F.3d 792, 807 (9th Cir. 2003) (applying the Rogers v. Grimaldi test, which requires courts to construe the Lanham Act "to apply to artistic works only where the public interest in avoiding consumer confusion outweighs the public interest in free expression" and "the title explicitly misleads as to the source or the content of the work").

258 Helfand, supra note 30, at 657.

259 Other characters that are in the public domain but are still being protected because of their popularity include Sherlock Holmes and Zorro. Eriq Gardner, Book Editor vs. Doyle Estate: Is Sherlock Holmes Still in Copyright?, THE HOLlywOOD REP. ESQUIRE (Feb. 15, 2013, 3:24 PM), http://www.hollywoodreporter.com/thr-esq/book-editor-doyle-estate-is-421918; Eriq Gardner, 'Zorro' Rights Challenged as Invalid and Fraudulent, THE HOLLYWOOD REP. ESQUIRE (Mar. 14, 2013, 9:59 AM), http://www.hollywoodreporter.com/thr-esq/zorro-rights-challenged-as-invalid-428561. The difference between these characters and Mickey Mouse is that these characters are not associated with one company as Mickey is. Parts of Sherlock Holmes are still under copyright due to the incremental expression test. See supra Section IV.A.

260 Helfand, supra note 30, at 664. 
public policy rationales."261 Copyright use of the character is now available for the public to use in new expressive works, but there is no good reason to take away the trademark if the owner is still using it because another company should not be able to use the marked character as a mark of its own. ${ }^{262}$

Courts should recognize that a character can seek protection under copyright and trademark law because it can function as both a mark used in commerce and as a unit of expression. ${ }^{263}$ Courts must therefore carefully evaluate the particular facts of each case to review the dual nature of a character in order to determine how the character is being used. ${ }^{264}$ For trademark, courts should evaluate infringement of a character in terms of its approach to non-character marks through a likelihood of confusion and secondary meaning analysis. ${ }^{265}$ For copyright, a court's evaluation must focus on what extent an alleged infringer has taken similar or identical expression comprising the character without taking into account how famous the character is or how well it is developed. ${ }^{266}$ The Supreme Court held in Dastar that others can copy public domain work without identification from its creative source and that trademark protection for a work in the public domain refers to the producer of the work. ${ }^{267}$ Thus someone can use a public domain character as his or her own without engaging in trademark infringement. ${ }^{268}$

By combining the exclusive rights given to copyright protection and trademark's term of protection for marks indicating source, "a character owner can prevent unauthorized uses of a character in perpetuity."269 Convergence of these causes of actions has two results: (1) character owners will control and profit from character uses not granted exclusively to them; and (2) a character's public domain status will become irrelevant if that character is unavailable to others for the creation of new expressive works. ${ }^{270}$ Utilizing trademark and unfair competition laws for a work no longer afforded copyright protection may well restrain expressive or

261 Id.

262 See id.

263 Id. at 662.

264 Id.

265 The analysis should be on whether there is confusion as to the source of the product that is making use of the character (whether it be a new work of fiction or on commercial merchandise). Thus, consumers must associate the character with a single source. Foley, supra note 73, at 942-44, 959.

266 Helfand, supra note 30, at 662; see generally Foley, supra note 73.

267 Dastar Corp. v. Twentieth Century Fox Film Corp., 539 U.S. 23, 33-37 (2003).

268 This should be true even if there is some consumer confusion because the character has such a strong secondary meaning with a mark owner. See infra notes 294-99 and accompanying text.

269 Helfand, supra note 30, at 654.

270 Id. at 662. 
ornamental uses that would otherwise be permitted through copyright law. ${ }^{271}$ This would lock up the entire market for a particular character; including any new characters that the mark owner thinks is too similar. ${ }^{272}$ Problems with mixing copyright and trademark law for characters are compounded when the character is granted trademark protection without a showing that the character is indicative of source because of unfair competition. ${ }^{273}$ The impact of trademark law on a mark owner's reputational interest has lessened because changes in trademark dilution law now protect parody and fair use more than it did before. ${ }^{274}$

Marvel and DC can also trademark logos and related indicia of characters if they have been used during the copyright term as indicators of source or origin. Like Superman's “S”, Batman's bat symbol, or SpiderMan's spider symbol, these character indicia become associated with the goods and services in which they appear. ${ }^{275}$ Use of these indicia as a part of the expression of the character should be allowed because it is not being used as an indicator of source, but rather as a part of the character's customary trait. ${ }^{276}$ Companies will therefore be allowed to protect characters and their indicia as marks for uses that serve identifying functions, and then only where the company is able to prove secondary meaning for the mark and that a likelihood of confusion exists from an alleged infringement. ${ }^{277}$

Allowing trademark protection against expressive uses of characters should be based on the commercial value of the characters derived from the plaintiff's efforts, whether the defendant is seeking the exclusive use of the character in a new work, and how close the fit between the alleged

271 Id. at 641 n.101. See Boston Prof'l Hockey Ass’n v. Dallas Cap \& Emblem Mfg., 510 F.2d 1004 (5th Cir. 1975) (hockey team motifs were trademarked, not copyrighted, but company that sold expressive emblems with the team motifs on them unattached to any other good or service was held liable for trademark infringement); see also Dallas Cowboys Cheerleaders, Inc. v. Pussycat Cinema, Ltd., 604 F.2d 200 (2d. Cir. 1979) (porn producer was liable for trademark infringement for costumes that were identical to cheerleader outfit because it could hurt mark owner's reputational interest). These cases show that unauthorized expressive uses of a mark can be considered infringement and are relevant for character marks that indicate source because even though the character has no copyright protection, it can still be blocked from expressive use by others through trademark law.

272 Helfand, supra note 30, at 641 n.101.

273 Id.; see also Universal City Studios, Inc. v. Nintendo Co., 746 F.2d 112 (2d Cir. 1984) (image of King Kong is recognizable, but does not identify a single authorizing source, so new uses of the image do not implicate the reputation of the character owner).

274 Dallas Cowboys, 604 F.2d 200, would probably be decided differently today as a form of satire or parody under $\S 43(c)$ of the Lanham Act (15 U.S.C. $\S 1125(c)$ ). This is a benefit for marked characters that survive after entering the public domain because it puts a limit on a possible indefinite copyright.

275 Helfand, supra note 30, 665 n.232.

276 Id

277 See infra note 283 and accompanying text. 
infringing act and past uses of the character mark by the plaintiff is. ${ }^{278}$ Courts should presume that the use of a character is merely decoration if it appears on the product itself rather than the label, tag, or packaging because consumers buy the product because of the character rather than the source of the character. ${ }^{279}$ If the consumer does not buy the product because of its source and buys it merely because of recognition of the character, then the character is not an indicator of source. ${ }^{280}$ If the character's status is merely a decoration, then copyright law will be used. ${ }^{281}$ If the decoration of the character has come to represent that the article comes from a certain source, then trademark analysis will need to be used as well as copyright law. ${ }^{282}$ If the product is a noncommercial use, such as a film or song, then the use of the character is not trademark-related. ${ }^{283}$

Two sources of confusion exist for characters that have gone into the public domain or are no longer owned by a company due to the author's use of termination rights: (1) that the public will continue to associate any works containing the character with the previous owner; and (2) that the continued use of the character trademark in expressive or derivative works will reinforce the consumer's association of the character mark with the mark owner. ${ }^{284}$ Unless the plaintiff proves secondary meaning and

278 See Helfand supra note 30, at 667-68. For the first factor, expressive uses of the mark should not solely rely on the character's popularity. Owning a trademark in a character does not prevent unauthorized uses of that trademark to be used by another for communicating ideas or expressing points of view. See Mattel, Inc. v. MCA Records, Inc., 296 F.3d 894, 900-01 (9th Cir. 2002). Expressive uses that use the commercial value of the character to gain attention rather than make a comment should not be allowed. See id. For the second factor, the expressive use of a character mark should be available for all. The use of a character mark for attention-seeking rather than creative expression can be shown if the defendant is trying to block others from using the mark in their works. For the third factor, an expressive use of a mark should be ornamental in nature and not try to signify source. There is a higher likelihood of confusion if the expressive use is similar to a logo because the fit between the uses of the character is the same between the works of the mark owner and new expressive works.

279 Helfand, supra note 30, at 668.

280 See id.

281 See id. at 667; see also Fleischer Studios v. A.V.E.L.A., Inc., 636 F.3d 1115, 1123-24 (9th Cir. 2011), withdrawn by Fleischer Studios, Inc., v. A.V.E.L.A., Inc., 654 F.3d 958 (9th Cir. 2011).

282 Helfand, supra note 30, at 667. A character's name that is in the public domain can also be used in new works. Id. at 669. The main concern in using a name in other works is whether there will be confusion as to source, and this requires an examination of defendant's marketing strategies because a use of a name alone does not indicate confusion. Id. For example, Snow White is a character name in the public domain but is highly associated with Disney. But even though the character has a secondary meaning with Disney, a different interpretation of the character will not lead to confusing that character with Disney. The character has been used outside Disney by other studios and has also been in the title ("Snow White and The Huntsman"), but this does not cause confusion as to source because Universal did not try to confuse consumers that the movie was being made by Disney. Universal was the creator of that film, not Disney.

283 Courts have interpreted the term "noncommercial" to include communicative uses. See Mattel, Inc. v. MCA Records Inc., 296 F.3d 894, 905-06 (9th Cir. 2002).

284 Helfand, supra note 30, at 669. 
likelihood of confusion, others should not be prevented from using the character because a character that acts only as a weak mark does not cause an association in the mind of the consumer between the character and the company. ${ }^{285}$ One measure to prevent confusion for uses of the character previously owned by another is to have a disclaimer that states the new work is not authorized or sponsored by the original author, previous copyright owner, or current trademark owner. ${ }^{286}$ Thus a character in the public domain or one returned to the author can be used in new expressive works while having a lesser likelihood of confusion. ${ }^{287}$

A few rare situations will occur with some characters where the character is synonymous with its source and any further expressive uses of the character will be prohibited. This absolute association between character and owner will arise where: (1) a single source uses the character both in expressive works and for trademark purposes during most, if not all, of its copyright term; (2) such use continues after the character enters the public domain; (3) the owner reviews any licensing quality; and (4) the owner polices the mark. ${ }^{288}$ Clear examples of this phenomenon include Walt Disney’s Mickey Mouse, Charles Schultz's Peanuts gang, ${ }^{289}$ Star Wars characters, ${ }^{290}$ Dr. Seuss characters, and prominent comic book characters including Batman, Superman, and Spider-Man. ${ }^{291}$

Companies could argue that expressive uses of these characters in the public domain should be limited "because the mere presence of them is enough, even for ornamental uses sporting disclaimer language, to evoke an association" in the consumer's mind to the mark owner. ${ }^{292}$ The argument

285 See id. at 669-70; Foley, supra note 73, at 942-44, 959.

286 Helfand, supra note 30, at 670; see also Liu, supra note 241, at 1433. Examples of this can be found on fan films or parodies done on YouTube.

287 However, if the character is used solely to designate origin or source, then the fact that the character is in the public domain and has a disclaimer is irrelevant. Helfand, supra note 30, at 671 n.258. If it is an author who now has full copyright to the character but the previous owner uses the character as a trademark, then a licensing agreement will have to be put into place or else the character is useless to both parties. See Krueger, supra note 38, at 247-48; see also Bouchat v. Baltimore Ravens, Inc., 241 F.3d 350 (4th Cir. 2000) (involved infringement of a copyrighted image, but that image was also used as a trademark by the infringer). One defense for an incidental use of a logo or character that is both copyrighted and trademark is fair use. Eriq Gardner, Appeals Court Won't Penalize NFL Network for Use of Artist's Logo, THE HOLLYWOOD REP. ESQUIRE (Dec. 17, 2013, 2:57 PM), http://www.hollywoodreporter.com/thr-esq/appeals-court-wont-penalize-nfl-666373.

288 Helfand, supra note 30, at 671.

289 Id

290 See Ideal Toy Corp. v. Kenner Prods. Div. of Gen. Mills Fun Grp., Inc., 443 F.Supp. 291, 301 (S.D.N.Y. 1977).

291 Helfand, supra note 30, at $671 \mathrm{n} .261$.

292 Id. at 671-72; see also Liu, supra note 241, at 1429-30. The prototypical features of the character can still be duplicated because the character is no longer protected by the substantial similarity test and limits on trademark dilution allow noncommercial uses. 
would say there will be a loss to consumers because with different variations of the characters from different users, there will be a lack of a coherent vision of the character. ${ }^{293}$ If this argument prevails, any rare limitation on expressive uses of characters can be lost after the characters start becoming associated with more than a single source ${ }^{294}$ because consumers who want a singular vision of a character can access the authorized version of the character by looking for the company's trademark. $^{295}$

Even where some consumer confusion might be possible for iconic works, trademark law should not be interpreted so broadly "as to limit the use of items that other areas of federal law have expressly placed into the public domain.”296 The Supreme Court has already held that consumer confusion under trademark law cannot undercut the purpose of patent law. In Kellogg Co. $v$ National Biscuit Company, ${ }^{297}$ the National Biscuit Company had the exclusive use of a shredded wheat cereal under a patent, but when the patent expired Kellogg began making the cereal under the term "shredded wheat." "298 The Court recognized that consumers might in fact associate the term "shredded wheat" with National Biscuit due to the company's long period of exclusive use, ${ }^{299}$ but held that competitors had the right to sell shredded wheat after the patent expired as well as accurately label the product as shredded wheat. ${ }^{300}$ "There is no reason in principle why the same understanding should not be applied to copyright law" and the Court's decision in Dastar shows that the Court is serious about not letting trademark law limit the public domain. ${ }^{301}$

293 See Liu, supra note 241, at 1422-23.

294 Id. at 1436.

295 See id. at 1424. Another theory for products that are so well connected with a certain company is to ask Congress to provide extended protection for certain works based on this mass consumer association between the work and the company. An argument for getting around the perpetual copyright issues would be to make this extended protection based on a renewal with a substantial fee, thus giving extended protection to certain works only if it is worth it to the company or heirs. See Eriq Gardner, U.S. Congressmen Told About 'Next Great Copyright Act' at Hearing, THE HollywoOd ReP. ESQUIRE (Mar. 20, 2013, 3:51 PM). It is unknown whether something like this will ever be brought up by lobby groups or Congress because a renewal of rights goes against the terms of the Berne Convention.

296 Liu, supra note 241, at 1431.

297305 U.S. 111 (1938).

298 Id. at $113-14$.

299 See id. at 121.

300 Id. at 119.

301 Liu, supra note 241, at 1431. A company would still be able to retain rights against classic trademark uses, such as if a competitor uses the character on a logo. See id. at 1433. 


\section{CONCLUSION}

Regardless of issues over copyright duration and termination rights, movie studios will continue to exploit comic book characters in film. Disney and Marvel are getting ready for a new slate of comic book films, as well as other studios with Marvel's licensed characters, ${ }^{302}$ and WB and DC are looking ahead at a "Justice League" movie that will create a shared universe. ${ }^{303}$ Other movies based on comic book characters are being made that are not based on the major characters from Marvel and DC, ${ }^{304}$ but it is likely that these films will make only a fraction of what the films with the popular characters will make. ${ }^{305}$ Because most of these popular characters are blocked from the market and this limitation comes from vertical agreements between comic book publishers and media companies, copyright duration and termination rights should be resolved in favor of the public domain and authors.

It is expected that companies will lose millions in revenue from losing

302 Ben Pearson, Mark Millar Now Consulting on All Marvel Films at 20th Century Fox, FIRST SHOwING (Sept. 27, 2012), http://www.firstshowing.net/2012/mark-millar-now-consutling-on-allmarvel-films-at-20th-century-fox/. "The Amazing Spider-Man” is being planned as a quadrilogy with more films in development. Peter Sciretta, 'The Amazing Spider-Man 3 and 4' Announced, SLASH FILM (June 17, 2013), http://www.slashfilm.com/the-amazing-spider-man-3-and-4-announced/. Additionally, several films are in development for the "X-Men" franchise. David Bentley, Ten Future X-Men Films Lined up by 20th Century Fox, with X-Force and Cable Among Possibilities, THE GeEK FILES (Nov. 13, 2012, 12:04 AM), http://blogs.coventrytelegraph.net/thegeekfiles/2012/11/ten-future-x-men-films-linedup-by-20th-century-fox-with-x-force-and-cable-among-possibilities.html; Graeme McMillan, Bryan Singer: 'X-Men: Apocalypse' More of a 'First Class' Follow-Up, THE HollywoOd ReP. HEAT Vision (Jan. 31, 2014, 11:28 AM), http://www.hollywoodreporter.com/heat-vision/bryan-singer-x-menapocalypse-676138.

303 Rick Marshall, Warner Bros. Planning Nine DC Comics Movies After Man of Steel Sequel and Justice League, DigITAL TRENDS (Apr. 29, 2014), http://www.digitaltrends.com/gaming/warnerbros-planning-nine-dc-comics-movies-man-steel-sequel-justice-league/\#!Kncvc. It is interesting to note that these shared universes of comic book characters would likely not be available unless one movie studio owned the rights to all these characters, which is the current issue under this regime, or movie studios with several different licensing agreements somehow agreed to merge the characters together for a movie. This article does not seek to say whether the shared film universes being created by the film studios are a bad thing (considering that this is how the comic industry has been for the past century). This article merely uses the film industry as an example of how characters can be blocked from the rest of the market.

304 For example, "Red 2”, "R.I.P.D.”, and “2 Guns” are all films with ties to comic publishers besides Marvel and DC. "Kick-Ass 2" is based on the comic published by Marvel, but under its Icon imprint that allows authors to own all the rights in the comic. Kick-Ass (comics), WIKIPEDIA, http://en.wikipedia.org/wiki/Kick-Ass_\%28comics\%29 (last visited Jan. 1, 2014).

305 But consider that the first "Kick-Ass" film, which was good enough to earn a sequel, only made about \$48 million domestically. Kick-Ass, Box OfFICE MoJo, http://www.boxofficemojo.com/movies/?id=kickass.htm (last visited Mar. 8, 2014). While "The Avengers” made about \$623 million domestically. Marvel's The Avengers, Box OffiCE Mojo, http://www.boxofficemojo.com/movies/?id=avengers11.htm (last visited Mar. 8, 2014). "The Dark Knight Rises” made about \$448 million domestically. The Dark Knight Rises, Box Office Mojo, http://www.boxofficemojo.com/movies/?id=batman3.htm (last visited Mar. 8, 2014). 
the exclusive right to use certain characters, but this loss is justified because companies earn that revenue by using copyright law to restrict free dissemination and prevent competition. ${ }^{306}$ Comic book characters continue to be exploited for nearly one hundred years before entering the public domain and the characters should be available to others for expressive uses. This can be accomplished by the character entering the public domain or terminating to the original author so the author can make new uses of the character. Companies can continue to exploit characters and protect them through trademark law if the character is a mark, but courts must take care to not rule against uses of the character that are purely expressive. Using the character in artwork or new stories that do not involve confusion as to the source of the character should not be held as an infringement. ${ }^{307}$

Termination cases will likely increase in number and complexity in this era for new works termination, ${ }^{308}$ so authors and companies should prepare to discuss ownership and termination from the very beginning. Authors and companies should be able to work together to exploit the full potential of characters because otherwise there will be drawn out legal battles and companies will lobby to reduce or eliminate termination rights. ${ }^{309}$ Companies can protect their interests in a character by deeming the work to be made for hire in the agreement. ${ }^{310}$ Companies can also continue to exploit the derivative works the character was used in during the term of the grant even after an author exercises his termination rights.

Disputes over ownership of comic book characters will likely die down because most work done for the major comic book publishers are now all done on a work made for hire basis. But because these characters are so popular and valuable, any argument over the ownership of some of these characters can potentially deal with millions of dollars. The heirs of Jack Kirby are appealing their case to the Supreme Court and claim that the "instance and expense test" is overbroad. ${ }^{311}$ The suit against Disney by

306 Liu, supra note 241, at 1422. This is a private loss to the companies, but not a net social loss as "the public will reap substantial benefits from the public domain status of these works and their subsequent wide dissemination.” Id.

307 See supra note 285 and accompanying text.

308 Valenzi, supra note 97, at 254.

309 Intellectual property provisions were leaked from the negotiations for the Trans-Pacific Partnership Agreement that show attempts to undermine termination rights. Parker Higgins \& Sarah Jeong, The TPP's Attack on Artist's Termination Rights, ELEC. FronTIER FounD. (Dec. 16, 2013), https://www.eff.org/deeplinks/2013/12/tpps-attack-artists-termination-rights\#.

310 Or by following the principles of general common law of agency for a court to hold a work was made by an employee or independent contractor. See supra note 101 and accompanying text.

311 Kevin Melrose, Supreme Court to Decide Next Week Whether to Hear Kirby case, COMIC BoOK RES. RoвOT 6 (May 6, 2014, 7:00 AM), http://robot6.comicbookresources.com/2014/05/supremecourt-to-decide-next-week-whether-to-hear-kirby-case/. 
Stan Lee Media was eventually dismissed with prejudice, ${ }^{312}$ but the issue of who owns the rights to several prominent Marvel characters was brought up again by a theater company that was using Spider-Man in a musical revue. ${ }^{313}$ The theater company claimed that Marvel did not own Spider-Man and that the character rightfully belonged to Stan Lee Media, which licensed the rights of the character to the theater company. ${ }^{314}$ Stan Lee Media later filed papers asking for a declaratory judgment that it owned the rights to Spider-Man. ${ }^{315}$ With millions of dollars at stake and the potential for billions of dollars in future profits, Disney will likely battle it out with full force until a final decision is made regarding the true ownership of these prominent comic book characters.

312 Dominic Patten, Disney Wins Dismissal of Marvel Copyright Lawsuit with Stan Lee Media, DEAdLINE HollywoOd (Sept. 5, 2013, 5:30 PM), http://www.deadline.com/2013/09/disney-winsdismissal-of-marvel-heroes-copyright-lawsuit-with-stan-lee-media/.

313 Kevin Melrose, Theaters Claims it Licensed Spider-Man from Stan Lee Media, СомIC BooK REs. Rовот 6 (Nov. 6, 2013, 8:00 AM), http://robot6.comicbookresources.com/2013/11/theater-claimsit-licensed-spider-man-from-stan-lee-media/.

314 Id.

315 Kevin Melrose, Stan Lee Media Takes Another Stab at Marvel Character Rights, ComIC BooK REs. RoвOT 6 (Dec. 5, 2013, 8:00 AM), http://robot6.comicbookresources.com/2013/12/stan-leemedia-takes-another-stab-at-marvel-character-rights/. Stan Lee Media has also filed an intervenor complaint seeking to assert its rights to Spider-Man. David McAfee, Stan Lee Media Sues Disney Unit in Spider-Man License Row, LAW 360 (Feb. 7, 2014, 8:24 PM), http://www.law360.com/articles/508343/stan-lee-media-sues-disney-unit-in-spider-man-license-row. Disney wants the judge to send a message that this will be the final time Stan Lee Media attempts to assert rights to Marvel characters. Eriq Gardner, Disney Demands End to Stan Lee Media's Claim to Own Spider-Man, THE Hollywood Rep. EsquiRe (Feb. 18, 2014, 3:07 PM), http://www.hollywoodreporter.com/thr-esq/disney-demands-end-stan-lee-681237. 